\title{
EVALUATION OF THE METALLIC TRACE ELEMENT CONTAMINATION OF COMMON SOLE (SOLEA SOLEA, L. 1758) BY THE WESTERN ALGERIAN COAST
}

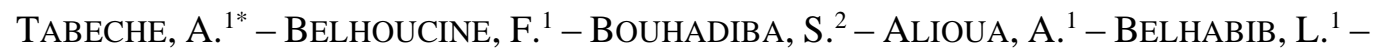 \\ ROUABHI, Y. L. ${ }^{3}$ \\ ${ }^{1}$ Laboratory Toxicology Environment and Health (LATES), Department of Life and the \\ Environment, University of Sciences and Technology Oran-Mohamed Boudiaf USTO-MB, El \\ Mnaouar, BP 1505, Bir El Djir 31000, Oran, Algeria \\ ${ }^{2}$ Laboratory Toxicology Environment and Health (LATES), Higher School of Biological \\ Sciences in Oran (ESSBO), BP 1042, Saim Mohamed 31003, Oran, Algeria \\ ${ }^{3}$ Laboratory Network for Environmental Monitoring (LRSE), Department of Biology, University \\ of Oran 1, Oran, Algeria \\ *Corresponding author \\ e-mail:ali.tabeche@univ-usto.dz \\ (Received $27^{\text {th }}$ Jun 2021; accepted $1^{\text {st }}$ Oct 2021)
}

\begin{abstract}
Metal contamination is one of the most worrying risks today. Our study is interested in the compartmentalisation of metallic trace elements in organs; gills, gonads and liver of common soles (Solea solea, L. 1758) from the western region of Algeria. The fish were collected seasonally between October 2018 and September 2019 in the two largest port areas of this region; Oran and Ghazaouet. Samples were compared by temperature, $\mathrm{pH}$, salinity, dissolved oxygen and organic matter. The concentrations of four metallic trace elements: zinc $(\mathrm{Zn})$, copper $(\mathrm{Cu})$, lead $(\mathrm{Pb})$ and cadmium $(\mathrm{Cd})$ were analyzed by atomic absorption spectrophotometry. From a statistical point of view, according to (Anova, $F$ value $=0.01, p$ value $=0.99)$, The results obtained from the average concentrations of the four metallic trace elements analyzed at the level of the organs showed no significant variation between the sampling sites and between the two sexes. On the other hand, for the three organs studied taken separately, we demonstrated a significant variation between the seasons for each of the metals studied. $\mathrm{Pb}$ concentrations were higher in sole organs collected from Oran Bay $\left(2.02 \pm 0.75 \mu \mathrm{g} . \mathrm{g}^{-1} \mathrm{dw}\right)$ than those from Ghazaouet Bay $\left(1.44 \pm 0.41 \mu \mathrm{g} \cdot \mathrm{g}_{\mathrm{dw}}^{-1}\right)$. These results do not reveal the origin of the micropollutants but they focus on the existence of this pollution which requires wider monitoring.

Keywords: metal pollution, atomic absorption spectrophotometry, physico-chemical parameters, Oran Bay, Ghazaouet Bay
\end{abstract}

\section{Introduction}

Marine pollution is one of the most worrying problems today. It is often emitted as a result of anthropogenic activities, such as industrial activities, agriculture or even domestic activities and in different forms (e.g., pesticides, hydrocarbons, metallic trace elements, etc.) (Aydoğan and İncekara, 2017; Pal et al., 2018).

Aquatic ecosystems are the most affected by metal pollution (Rodrigue et al., 2016). This chemical contamination can represent a toxicological risk and affect marine life. Lead and cadmium are considered toxic elements in high concentrations, $\mathrm{Cu}$ and $\mathrm{Zn}$ are trace elements but can become dangerous if they exceed a certain threshold in the body (Borsali, 2015). By their resistance to biodegradation, their persistence and their toxicity, these elements can concentrate in the tissues of living organisms (Förstner and Wittmann, 1981; Boucheseiche et al., 2002). These organisms then enter the food chain. If the product is not 
degraded or eliminated, it will concentrate more and more at each level of the food chain. Indeed, heavy metals are poorly metabolized. They can therefore be transferred into the food web and accumulated in living matter (Duquesne, 1992).

In recent years, the monitoring of metallic contamination in the marine environment relied solely on the chemical analysis of the water (Lafabrie, 2007). In addition, this analytical technique does not provide information on the bioavailability of trace metal elements for organisms and does not allow to assess, or even predict, the impact of these substances on organisms or, on the ecosystem as a whole (Lagadic et al., 1998; Morillo et al., 2005). Fish have been shown to be vectors of trace metal contamination in humans, so some species are now used as biological tools for assessing trace metal pollution in water (Goldberg, 1975).

Various studies have shown that xenobiotics cause disturbances in the reproductive system, changes in behavior, disturbances in energy metabolism and the appearance of mutagenic or carcinogenic effects in aquatic species (Meyer, 2003). Pollution can have repercussions on all food chains, from primary producers to final consumers and, consequently, alter the functioning of ecosystems (Borsali, 2015). Chemical contaminants can have cascading effects on the growth and reproduction of organisms, leading to changes in higher biological organization, in populations and communities (Amiard-Triquet and Amiard, 2008).

Pollution in Algeria is mainly generated by discharges of untreated industrial and urban water (Taleb et al., 2007; Grimes et al., 2010). Petrochemical, chemical, steel and agrifood activities are mainly concentrated on the Algerian coastal strip (Grimes et al., 2010).

Our choice fell on the common sole (Solea solea, L. 1758), it is a fish that is widespread on the Algerian coasts and consumed by a large part of the population. According to Wessel (2010), this species is particularly sensitive to anthropogenic pressure. Indeed, due to its benthic way of life, it is constantly in contact with sediments, reservoirs of many contaminants including trace metals. It should be noted that at the level of the Algerian west coast, common sole has never been used as a bio indicator of metal pollution to date, hence the interest of its choice and in order to complement the various research projects relating to the installation of a monitoring network for marine pollution and fishery products in the same region.

\section{Materials and methods}

\section{Study area}

Algeria has a wide maritime frontage which is located in the heart of the Mediterranean. From an ecological point of view, its coastline is rich and diverse, and alternates between rocky shores, sandy beaches and wetlands (Benzohra and Millot, 1995). Two sites were selected for our study, Oran Bay and Ghazaouet Bay.

The bay of Oran with a latitude of $35^{\circ} 43^{\prime}$ North and a longitude of $00^{\circ} 38^{\prime}$ 'West (Fig. 1) occupies the central part of the Oran coast (Belhoucine et al., 2014). The Oran coast is severely affected by the nuisances of the civilized world: industrial activities, intensive tourism and massive urbanization with an ever-increasing level of domestic pollution (Kerfouf et al., 2010).

The bay of Ghazaouet with a latitude of $35^{\circ} 06^{\prime}$ North and a longitude of $1^{\circ} 52^{\prime}$ West (Fig. 1) is located at the western end of Algeria. This area is subjected to industrial wastewater from the zinc electrolysis unit ALZINC (Algerian Zinc Company by abbreviation is a subsidiary of METANOF), these discharges loaded with metallic trace 
elements, contributed to the uncontrolled storage of leaching waste from zinc on the cliff overlooking the sea and the factory (DPRHT, 2004). This unit is currently the most important industrial activity center in the region, being the only producer of electrolytic zinc in the Arab world and the second in Africa after South Africa.

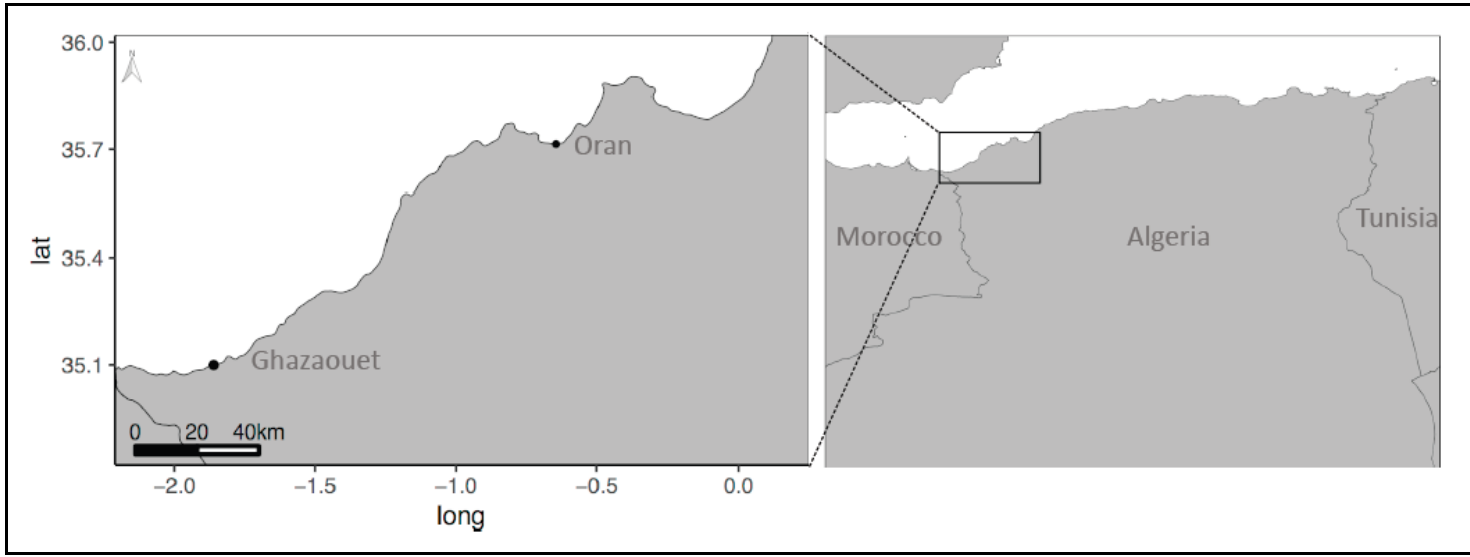

Figure 1. Location of the study area: Oran bay and Ghazaouet bay

\section{Sample collection and processing}

Sampling was carried out seasonally between October 2018 and September 2019 at the two sites (one day per month). In total, we collected 120 individuals of Solea solea (L. 1758) from the fishing ports. The samples were processed the same day at the laboratory level. After the biometric measurements, the fish were dissected in order to remove the liver, gills and gonads.

Sampling of fish was accompanied by sampling of seawater. A liter of water was taken from the surface, using polyethylene bottles, washed and rinsed with distilled water, then transported to the laboratory in the cooler to be stored at $+4{ }^{\circ} \mathrm{C}$ until analysis.

Temperature, $\mathrm{pH}$, salinity, dissolved oxygen and organic matter were measured using the multi-parameter instrument (WTW Multi 340i).

\section{Extraction and analysis of ETMs $(\mathrm{Pb}, \mathrm{Cu}, \mathrm{Zn}$ and $\mathrm{Cd})$}

Before carrying out the analysis of the metals in the various organs studied, the samples studied had been mineralized (Chiffoleau et al., 2001). This step consists of the destruction of the organic matter by an acid attack (pure nitric acid $\mathrm{HNO}_{3}$ ). The subsamples were dried in an oven at $60{ }^{\circ} \mathrm{C}$ until a constant weight was obtained (24 to $72 \mathrm{~h}$ ), then crushed. $0.2 \mathrm{~g}$ of dried sample for each replica, had been mineralized in $4 \mathrm{ml}$ of pure $\mathrm{HNO}_{3}$ at room temperature overnight, then placed in an oven at $90{ }^{\circ} \mathrm{C}$ for $3 \mathrm{~h}$. The mineralisates were then filtered with wattman filter paper. The determination of the ETMs had been carried out by a flame atomic absorbance spectrophotometer of the Perkin Elmer precisely AAnalyst 400 type.

The verification of the absence of possible contamination of the samples during the analysis was made using the test blanks. These negative controls were treated according to the same protocol as the other samples in order to verify the validity of the method by ensuring that the compounds detected in the samples did not come from contamination during the analysis. 
The reliability of the protocol described above was also validated using a homogenized standard sample known as the intercalibration sample provided by the International Atomic Energy Agency (IAEA, 1995). In our case, this is a fish sample coded 140/TM.

\section{Statistical analyses}

First, a study of distribution and homogeneity had been carried out. The variations between sites, seasons and organs were analyzed with a multi-parameter Anova test followed by a post-hoc Duncan test.

In order to study the distribution of the data a Spearman correlation matrix and PCA were used. The minimum level of significance for all analyzes was 0.05 . The statistical analyzes were carried out in $\mathrm{R}$ version 3.4.2 (R Core Team, 2017), with the packages: RStudio v. 1.2.5033 (RStudio Team, 2019), ggplot2 (Wickham, 2016), corrgram (Wright, 2018), dplyr (Wickham et al., 2020), FSA (Ogle et al., 2020).

\section{Results}

The analysis (mean \pm standard deviation (SD)) of the physico-chemical parameters of the seawater in each of the two bays (Oran bay and Ghazaouet bay), recorded during the different seasons, are grouped together in Table 1.

Table 1. Averages the physico-chemical parameters of the coastal waters of the bay of Oran and the bay of Ghazaouet

\begin{tabular}{c|c|c}
\hline Parameter & Bay of Oran $($ mean \pm SD) & Bay of Ghazaouet (mean \pm SD) \\
\hline $\mathrm{T}^{\circ} \mathrm{C}$ & $21.25 \pm 6.85$ & $22.47 \pm 6.79$ \\
$\mathrm{pH}$ & $7.66 \pm 0.18$ & $7.75 \pm 0.11$ \\
Salinity $(\mathrm{PSU})$ & $36.57 \pm 0.67$ & $36.84 \pm 0.78$ \\
$\mathrm{O}_{2}$ dissolved $\left(\mathrm{mg} \mathrm{L}^{-1}\right)$ & $5.98 \pm 1.90$ & $6.39 \pm 1.16$ \\
Organic matter $\left(\mathrm{mg} \mathrm{L}^{-1}\right)$ & $15.14 \pm 0.88$ & $15.28 \pm 0.33$ \\
\hline
\end{tabular}

Figure 2 represents the average concentrations of the targeted metal trace elements zinc, copper, lead and cadmium in common sole (Solea solea, L. 1758) fished in the bay of Oran and in the bay of Ghazaouet.

The results of base Anova for the comparison of the metallic elements in the organs of the common sole fished in the two bays: Oran bay and Ghazaouet bay, are grouped in Table 2.

Figure 3 shows the comparison of the average concentrations of heavy metals studied in the hepatic, gonadal and branchial tissues in common sole (Solea solea, L. 1758) fished in the bay of Oran and the bay of Ghazaouet.

Our results showed significant seasonal variations of the four metallic trace elements, in the three organs of common sole fished in the bay of Oran. For liver, Zn (Anova 2, F value $=95.69, \mathrm{p}$ value $<0.001$ ), $\mathrm{Cu}$ (Anova 2, $\mathrm{F}$ value $=99.54, \mathrm{p}$ value $<0.001), \mathrm{Pb}$ (Anova 2, F value $=44.12, \mathrm{p}$ value $<0.001$ ) and $\mathrm{Cd}$ (Anova 2, F value $=31.35, \mathrm{p}$ value <0.001) (Tables 3 and 4). For the gills, $\mathrm{Zn}$ (Anova 2, F value $=255.10, \mathrm{p}$ value < 0.001), $\mathrm{Cu}$ (Anova 2, $\mathrm{F}$ value $=54.56, \mathrm{p}$ value $<0.001$ ), $\mathrm{Pb}$ (Anova 2, $\mathrm{F}$ value $=92.11, \mathrm{p}$ value $<0.001)$ and $\mathrm{Cd}$ (Anova $2, \mathrm{~F}$ value $=26.62, \mathrm{p}$ value $<0.001$ ) (Tables 3 and 5). For the gonads, $\mathrm{Zn}$ (Anova 2, F value $=182.72, \mathrm{p}$ value $<0.001$ ), $\mathrm{Cu}$ 
$($ Anova 2, $\mathrm{F}$ value $=37.97, \mathrm{p}$ value $<0.001), \mathrm{Pb}($ Anova $2, \mathrm{~F}$ value $=20.28, \mathrm{p}$ value $<0.001)$ and $\mathrm{Cd}$ (Anova $2, \mathrm{~F}$ value $=13.40$, $\mathrm{p}$ value $<0.001)($ Tables 3 and 6$)$.

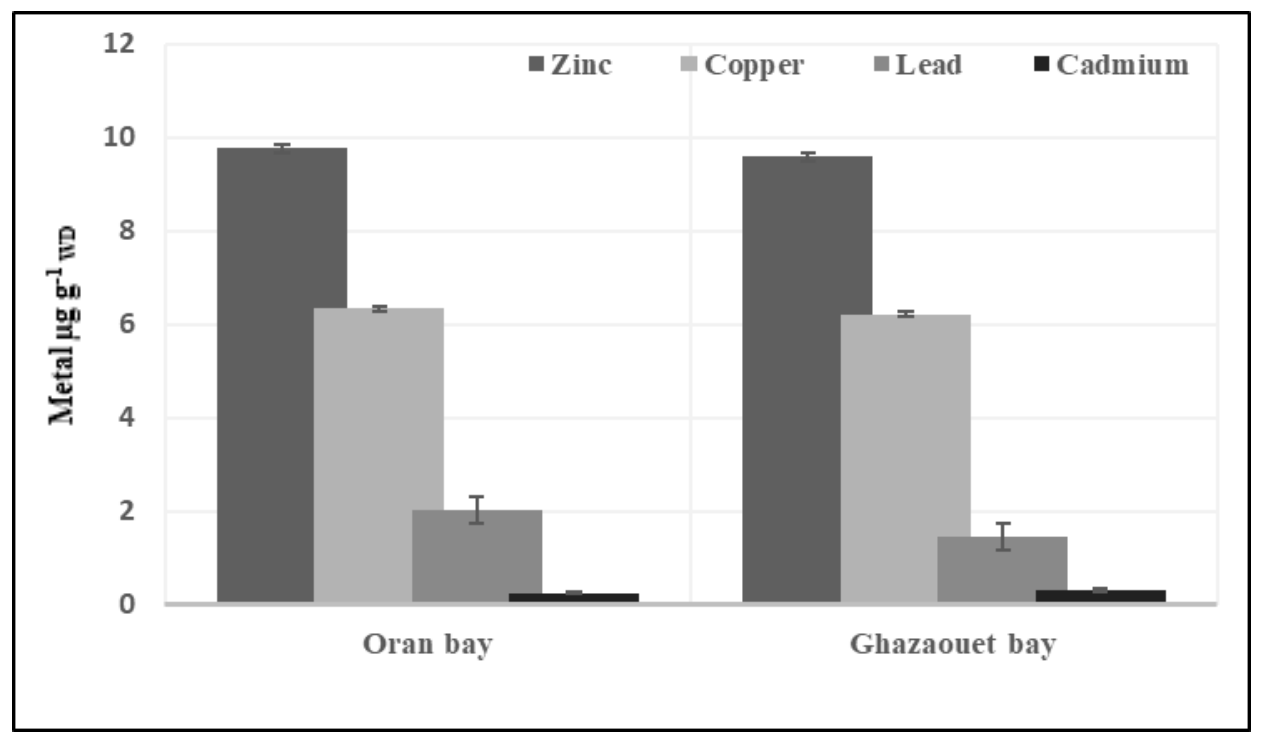

Figure 2. Average levels of metallic trace elements $(\mathrm{Zn}, \mathrm{Cu}, \mathrm{Pb}$ and $\mathrm{Cd})$ evaluated in sole fished in the two bays: Oran Bay and Ghazaouet Bay

Table 2. Anova base for the comparison of metallic elements in the organs of the common sole fished in the two bays: Oran Bay and Ghazaouet Bay

\begin{tabular}{c|c|c|c|c|c}
\hline Variable & Df & Sum of squares & Mean of squares & F value & p value \\
\hline Organ & 2 & 15.0 & 7.501 & 0.4751 & 0.6220893 \\
Sex & 1 & 11.6 & 11.593 & 0.7343 & 0.3918802 \\
Site & 1 & 6.1 & 6.111 & 0.3871 & 0.5341031 \\
Saison & 3 & 331.3 & 110.425 & 6.9945 & $<0.001 * * *$ \\
Organ: Sex & 2 & 5.0 & 2.503 & 0.1586 & 0.8534093 \\
Organ: Site & 2 & 0.5 & 0.269 & 0.0170 & 0.9830978 \\
Sex: Site & 1 & 0.7 & 0.696 & 0.0441 & 0.8337577 \\
Organ: Season & 6 & 2.8 & 0.465 & 0.0275 & 0.9998912 \\
Sex: Season & 3 & 0.2 & 0.041 & 0.0026 & 0.9998184 \\
Site: Season & 3 & 14.5 & 4.842 & 0.3067 & 0.8205793 \\
Organ: Sex: Site & 2 & 0.4 & 0.196 & 0.0124 & 0.9876370 \\
Organ: Sex: Season & 6 & 0.1 & 0.018 & 0.0011 & 1.0000000 \\
Organ: Site: Season & 6 & 1.0 & 0.167 & 0.0106 & 0.9999948 \\
Sex: Site: Season & 3 & 0.2 & 0.073 & 0.0046 & 0.9995671 \\
Organ: Sex: Site: Season & 6 & 0.3 & 0.057 & 0.0036 & 0.9999998 \\
\hline
\end{tabular}

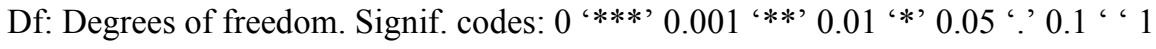

In Oran Bay, seasonal variations of metallic trace elements showed the highest average concentrations in the organs of fish collected mainly in summer, autumn and spring. The lowest concentrations were noted during the winter period (Fig. 4). 


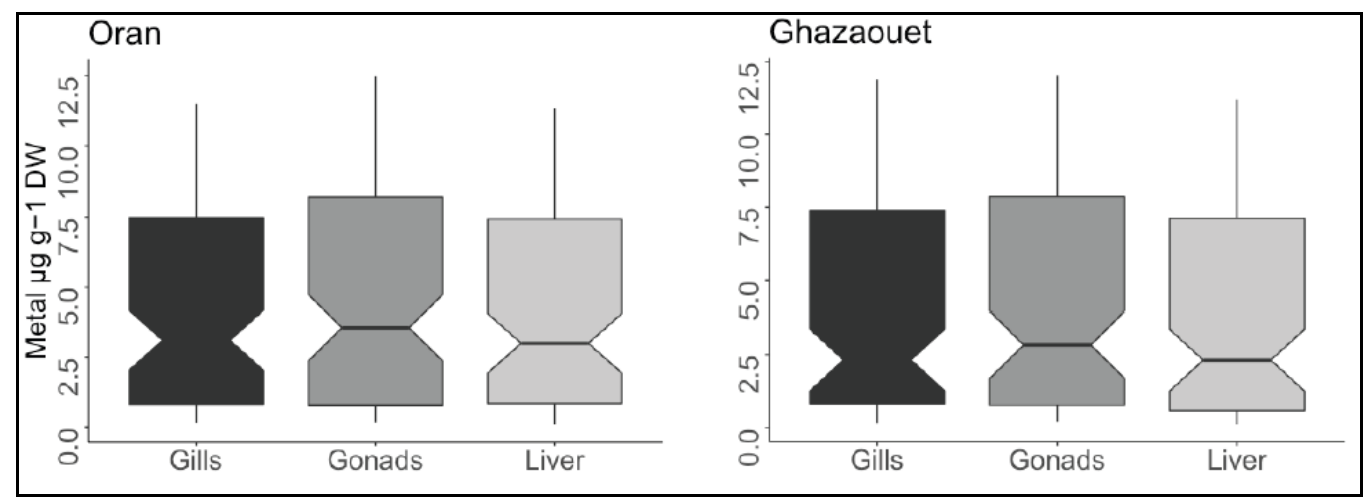

Figure 3. Comparison between metal organs combined in the two bays: Oran Bay and Ghazaouet Bay

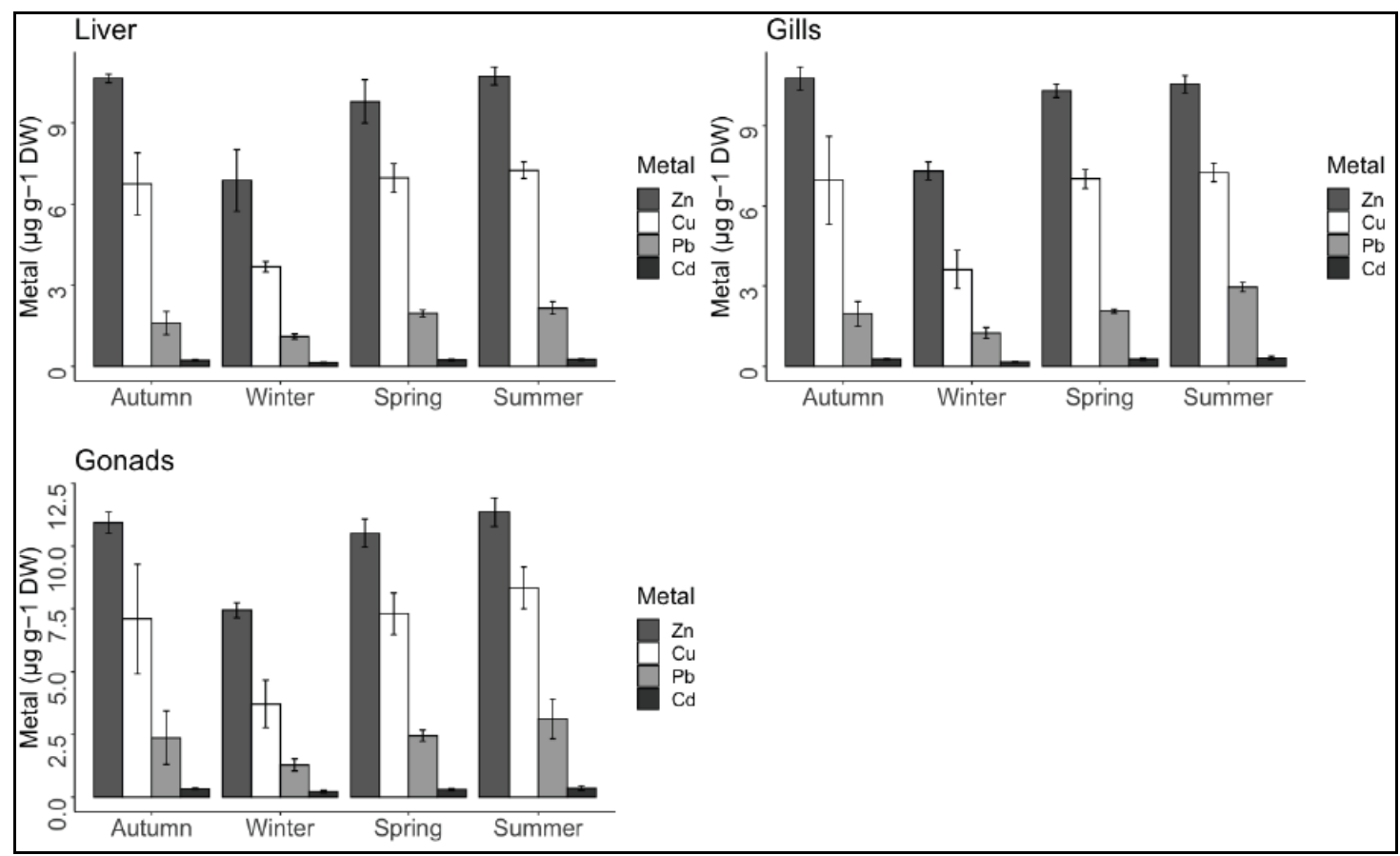

Figure 4. Seasonal variations of metals $(\mathrm{Zn}, \mathrm{Cu}, \mathrm{Pb}$ and $\mathrm{Cd})$ in organs at Oran bay

In the liver, the average concentrations of heavy metals: $\mathrm{Cd}, \mathrm{Cu}, \mathrm{Pb}$ and $\mathrm{Zn}$ recorded in the summer season were respectively equal to $0.25 \pm 0.03 \mu \mathrm{g} . \mathrm{g}^{-1} \mathrm{dw}, 7.25 \pm 0.31 \mu \mathrm{g} . \mathrm{g}^{-1} \mathrm{dw}$, $2.15 \pm 0.24 \mu \mathrm{g} . \mathrm{g}_{\mathrm{dw}}^{-1}, 10.74 \pm 0.34 \mu \mathrm{g} . \mathrm{g}^{-1} \mathrm{dw}$. In the winter season, their concentrations were $0.13 \pm 0.02 \mu \mathrm{g} \cdot \mathrm{g}_{\mathrm{dw}}^{-1}, 3.68 \pm 0.19 \mu \mathrm{g} . \mathrm{g}_{\mathrm{dw}}^{-1}, 1.10 \pm 0.09 \mu \mathrm{g} \cdot \mathrm{g}_{\mathrm{dw}}^{-1}, 6.87 \pm 1.14 \mu \mathrm{g}^{\mathrm{g}} \mathrm{g}^{-1} \mathrm{dw}$, respectively. In the gills, their mean concentrations in the summer season were $0.31 \pm 0.06 \mu \mathrm{g} \cdot \mathrm{g}_{\mathrm{dw}}^{-1}, 7.25 \pm 0.35 \mu \mathrm{g} \cdot \mathrm{g}_{\mathrm{dw}}^{-1}, 2.96 \pm 0.17 \mu \mathrm{g} \cdot \mathrm{g}_{\mathrm{dw}}^{-1}, 10.56 \pm 0.33 \mu \mathrm{g} \cdot \mathrm{g}_{\mathrm{dw}}^{-1}$ respectively. In the winter season, they were respectively equal to $0.16 \pm 0.02 \mu \mathrm{g} . \mathrm{g}-1 \mathrm{dw}$, $3.62 \pm 0.71 \mu \mathrm{g} . \mathrm{g}^{-1} \mathrm{dw}, 1.24 \pm 0.20 \mu \mathrm{g} \cdot \mathrm{g}_{\mathrm{dw}}^{-1}, 7.31 \pm 0.34 \mu \mathrm{g} . \mathrm{g}^{-1} \mathrm{dw}$. In the gonads, their mean concentrations were respectively equal to $0.35 \pm 0.08 \mu{\mathrm{g} . \mathrm{g}^{-1} \mathrm{dw}}, 8.34 \pm 0.84 \mu \mathrm{g} \cdot \mathrm{g}^{-1} \mathrm{dw}$, $3.12 \pm 0.79 \mu \mathrm{g} . \mathrm{g}^{-1} \mathrm{dw}, 11.36 \pm 0.57 \mu \mathrm{g} . \mathrm{g}^{-1} \mathrm{dw}$, in the summer period. During the winter, they reached $0.22 \pm 0.05 \mu \mathrm{g} . \mathrm{g}^{-1}{ }_{\mathrm{dw}}, 3.71 \pm 0.94 \mu \mathrm{g} \cdot \mathrm{g}^{-1} \mathrm{dw}, 1.28 \pm 0.24 \mu \mathrm{g} \cdot \mathrm{g}^{-1} \mathrm{dw}, 7.45 \pm 0.31 \mu \mathrm{g} \cdot \mathrm{g}^{-}$ $1_{\mathrm{dw}}$, respectively. 
Tabeche et al.: Evaluation of the metallic trace element contamination of common sole (Solea solea, L. 1758) by the western Algerian coast

-4647 -

Table 3. Anova base for seasonal variations of the four metallic trace elements ( $\mathrm{Zn}, \mathrm{Cu}, \mathrm{Pb}$ and $\mathrm{Cd}$ ) in the liver, in the gills and in the gonads of common sole fished in the bay of Oran

\begin{tabular}{c|c|c|c|c|c|c}
\hline Organ & Metal & Df & Sum of squares & Mean of squares & F value & p value \\
\hline \multirow{6}{*}{ Liver } & $\mathrm{Zn}$ & 3 & 49.282000 & 49.282000 & 95.692 & $<0.001 * * *$ \\
& $\mathrm{Cu}$ & 3 & 42.333000 & 42.333000 & 99.540 & $<0.001 * * *$ \\
& $\mathrm{~Pb}$ & 3 & 3.121180 & 3.121180 & 44.125 & $<0.001 * * *$ \\
& $\mathrm{Cd}$ & 3 & 0.044171 & 0.044171 & 31.348 & $<0.001 * * *$ \\
\hline \multirow{6}{*}{ Gills } & $\mathrm{Zn}$ & 3 & 40.708000 & 40.708000 & 255.100 & $<0.001 * * *$ \\
& $\mathrm{Cu}$ & 3 & 45.533000 & 45.533000 & 54.558 & $<0.001 * * *$ \\
& $\mathrm{~Pb}$ & 3 & 7.332600 & 7.332600 & 92.111 & $<0.001 * * *$ \\
& $\mathrm{Cd}$ & 3 & 0.065307 & 0.065307 & 26.622 & $<0.001 * * *$ \\
\hline \multirow{6}{*}{ Gonads } & $\mathrm{Zn}$ & 3 & 48.591600 & 48.591600 & 182.720 & $<0.001 * * *$ \\
& $\mathrm{Cu}$ & 3 & 60.605000 & 60.605000 & 37.973 & $<0.001 * * *$ \\
& $\mathrm{~Pb}$ & 3 & 9.202600 & 9.202600 & 20.285 & $<0.001 * * *$ \\
& $\mathrm{Cd}$ & 3 & 0.150060 & 0.050020 & 13.402 & $<0.001 * * *$ \\
\hline
\end{tabular}

Df: Degrees of freedom. Signif. codes: 0 ‘***’ 0.001 '**’ 0.01 ‘*’ 0.05 '? 0.1 ' ‘ 1

Table 4. The results of the post hoc test (Duncan test) of the seasonal variations for the four metallic trace elements ( $\mathrm{Zn}, \mathrm{Cu}, \mathrm{Pb}$ and $\mathrm{Cd})$ in the liver of common sole fished in the bay of Oran

\begin{tabular}{|c|c|c|c|}
\hline Organ & Metal & Comparison & $Z$ value \\
\hline \multirow{4}{*}{ Liver } & $\mathrm{Zn}$ & $\begin{array}{c}\text { Autumn - Spring } \\
\text { Autumn - Summer } \\
\text { Spring - Summer } \\
\text { Autumn - Winter } \\
\text { Spring - Winter } \\
\text { Summer - Winter }\end{array}$ & $\begin{array}{c}2.21 \\
-0.39 \\
-2.60 \\
5.27 \\
3.06 \\
5.66\end{array}$ \\
\hline & $\mathrm{Cu}$ & $\begin{array}{c}\text { Autumn - Spring } \\
\text { Autumn - Summer } \\
\text { Spring - Summer } \\
\text { Autumn - Winter } \\
\text { Spring - Winter } \\
\text { Summer - Winter }\end{array}$ & $\begin{array}{c}-0.33 \\
-1.20 \\
-0.87 \\
4.19 \\
4.53 \\
5.39 \\
\end{array}$ \\
\hline & $\mathrm{Pb}$ & $\begin{array}{l}\text { Autumn - Spring } \\
\text { Autumn - Summer } \\
\text { Spring - Summer } \\
\text { Autumn - Winter } \\
\text { Spring - Winter } \\
\text { Summer - Winter }\end{array}$ & $\begin{array}{c}-1.66 \\
-3.06 \\
-1.41 \\
2.71 \\
4.37 \\
5.78\end{array}$ \\
\hline & $\mathrm{Cd}$ & $\begin{array}{c}\text { Autumn - Spring } \\
\text { Autumn - Summer } \\
\text { Spring - Summer } \\
\text { Autumn - Winter } \\
\text { Spring - Winter } \\
\text { Summer - Winter }\end{array}$ & $\begin{array}{c}-0.73 \\
-1.55 \\
-0.82 \\
3.73 \\
4.46 \\
5.28 \\
\end{array}$ \\
\hline
\end{tabular}


Table 5. The results of the post hoc test (Duncan test) of the seasonal variations for the four metallic trace elements ( $\mathrm{Zn}, \mathrm{Cu}, \mathrm{Pb}$ and $\mathrm{Cd})$ in the gills of common sole fished in the bay of Oran

\begin{tabular}{|c|c|c|c|}
\hline Organ & Metal & Comparison & $Z$ value \\
\hline \multirow{4}{*}{ Gills } & $\mathrm{Zn}$ & $\begin{array}{c}\text { Autumn - Spring } \\
\text { Autumn - Summer } \\
\text { Spring - Summer } \\
\text { Autumn - Winter } \\
\text { Spring - Winter } \\
\text { Summer - Winter }\end{array}$ & $\begin{array}{c}2.25 \\
1.08 \\
-1.17 \\
5.81 \\
3.56 \\
4.74\end{array}$ \\
\hline & $\mathrm{Cu}$ & $\begin{array}{c}\text { Autumn - Spring } \\
\text { Autumn - Summer } \\
\text { Spring - Summer } \\
\text { Autumn - Winter } \\
\text { Spring - Winter } \\
\text { Summer - Winter }\end{array}$ & $\begin{array}{r}0.95 \\
0.08 \\
-0.87 \\
4.98 \\
4.03 \\
4.90 \\
\end{array}$ \\
\hline & $\mathrm{Pb}$ & $\begin{array}{c}\text { Autumn - Spring } \\
\text { Autumn - Summer } \\
\text { Spring - Summer } \\
\text { Autumn - Winter } \\
\text { Spring - Winter } \\
\text { Summer - Winter }\end{array}$ & $\begin{array}{c}-0.56 \\
-3.89 \\
-3.33 \\
2.96 \\
3.52 \\
6.85\end{array}$ \\
\hline & $\mathrm{Cd}$ & $\begin{array}{c}\text { Autumn - Spring } \\
\text { Autumn - Summer } \\
\text { Spring - Summer } \\
\text { Autumn - Winter } \\
\text { Spring - Winter } \\
\text { Summer - Winter }\end{array}$ & $\begin{array}{c}-0.44 \\
-1.38 \\
-0.94 \\
3.99 \\
4.43 \\
5.37\end{array}$ \\
\hline
\end{tabular}

Our results showed significant seasonal variations of the four metallic trace elements, in the three organs of common sole fished in the bay of Ghazaouet. For liver, $\mathrm{Zn}$ (Anova 2, F value $=57.24, \mathrm{p}$ value $<0.001), \mathrm{Cu}$ (Anova 2, $\mathrm{F}$ value $=68.23, \mathrm{p}$ value $<0.001), \mathrm{Pb}$ (Anova 2, F value $=51.69, \mathrm{p}$ value $<0.001$ ) and $\mathrm{Cd}$ (Anova 2, $\mathrm{F}$ value $=11.61, \mathrm{p}$ value $<0.001$ ) (Tables 7 and 8 ). For the gills, $\mathrm{Zn}$ (Anova 2, F value $=65.38, \mathrm{p}$ value $<0.001$ ), $\mathrm{Cu}$ (Anova $2, \mathrm{~F}$ value $=68.87, \mathrm{p}$ value $<0.001), \mathrm{Pb}$ (Anova 2, F value $=22.79, \mathrm{p}$ value $<0.001$ ) and $\mathrm{Cd}$ (Anova 2, F value $=59.87, \mathrm{p}$ value $<0.001$ ) (Tables 7 and 9). For the gonads, $\mathrm{Zn}$ (Anova 2, F value $=73.91, \mathrm{p}$ value <0.001), $\mathrm{Cu}$ (Anova 2, $\mathrm{F}$ value $=40.89, \mathrm{p}$ value $<0.001$ ), $\mathrm{Pb}$ (Anova 2, F value $=33.33, \mathrm{p}$ value $<0.001)$ and $\mathrm{Cd}$ (Anova $2, \mathrm{~F}$ value $=25.90, \mathrm{p}$ value $<0.001)$ (Tables 7 and 10). 
Table 6. The results of the post hoc test (Duncan test) of the seasonal variations for the four metallic trace elements ( $\mathrm{Zn}, \mathrm{Cu}, \mathrm{Pb}$ and $\mathrm{Cd})$ in the gonads of common sole fished in the bay of Oran

\begin{tabular}{|c|c|c|c|}
\hline Organ & Metal & Comparison & $Z$ value \\
\hline \multirow{4}{*}{ Gonads } & $\mathrm{Zn}$ & $\begin{array}{c}\text { Autumn - Spring } \\
\text { Autumn - Summer } \\
\text { Spring - Summer } \\
\text { Autumn - Winter } \\
\text { Spring - Winter } \\
\text { Summer - Winter }\end{array}$ & $\begin{array}{c}1.43 \\
-1.09 \\
-2.52 \\
4.82 \\
3.39 \\
5.91\end{array}$ \\
\hline & $\mathrm{Cu}$ & $\begin{array}{c}\text { Autumn - Spring } \\
\text { Autumn - Summer } \\
\text { Spring - Summer } \\
\text { Autumn - Winter } \\
\text { Spring - Winter } \\
\text { Summer - Winter }\end{array}$ & $\begin{array}{c}0.62 \\
-1.41 \\
-2.03 \\
4.18 \\
3.55 \\
5.59\end{array}$ \\
\hline & $\mathrm{Pb}$ & $\begin{array}{c}\text { Autumn - Spring } \\
\text { Autumn - Summer } \\
\text { Spring - Summer } \\
\text { Autumn - Winter } \\
\text { Spring - Winter } \\
\text { Summer - Winter }\end{array}$ & $\begin{array}{c}-0.79 \\
-2.50 \\
-1.71 \\
3.46 \\
4.26 \\
5.97\end{array}$ \\
\hline & $\mathrm{Cd}$ & $\begin{array}{c}\text { Autumn - Spring } \\
\text { Autumn - Summer } \\
\text { Spring - Summer } \\
\text { Autumn - Winter } \\
\text { Spring - Winter } \\
\text { Summer - Winter }\end{array}$ & $\begin{array}{c}0.97 \\
0.02 \\
-0.95 \\
4.20 \\
3.22 \\
4.18\end{array}$ \\
\hline
\end{tabular}

Table 7. Anova base for seasonal variations of the four metallic trace elements ( $\mathrm{Zn}, \mathrm{Cu}, \mathrm{Pb}$ and $C d$ ) in the liver, in the gills and in the gonads of common sole fished in the bay of Ghazaouet

\begin{tabular}{c|c|c|c|c|c|c}
\hline Organ & Metal & Df & Sum of squares & Mean of squares & F value & p value \\
\hline \multirow{6}{*}{ Liver } & $\mathrm{Zn}$ & 3 & 73.021000 & 24.340200 & 57.245 & $<0.001 * * *$ \\
& $\mathrm{Cu}$ & 3 & 64.248000 & 21.416100 & 68.232 & $<0.001 * * *$ \\
& $\mathrm{~Pb}$ & 3 & 7.931300 & 2.643770 & 51.691 & $<0.001 * * *$ \\
& $\mathrm{Cd}$ & 3 & 0.124560 & 0.041522 & 11.614 & $<0.001 * * *$ \\
\hline \multirow{6}{*}{ Gills } & $\mathrm{Zn}$ & 3 & 84.897000 & 28.299100 & 65.381 & $<0.001 * * *$ \\
& $\mathrm{Cu}$ & 3 & 88.807000 & 29.602200 & 68.871 & $<0.001 * * *$ \\
& $\mathrm{~Pb}$ & 3 & 4.568400 & 1.522790 & 22.786 & $<0.001 * * *$ \\
& $\mathrm{Cd}$ & 3 & 0.418330 & 0.139444 & 59.872 & $<0.001 * * *$ \\
\hline \multirow{6}{*}{ Gonads } & $\mathrm{Zn}$ & 3 & 91.703000 & 30.567800 & 73.914 & $<0.001 * * *$ \\
& $\mathrm{Cu}$ & 3 & 56.443000 & 18.814500 & 40.892 & $<0.001^{* * *}$ \\
& $\mathrm{~Pb}$ & 3 & 7.359500 & 2.453200 & 33.33 & $<0.001 * * *$ \\
& $\mathrm{Cd}$ & 3 & 0.120684 & 0.068947 & 25.897 & $<0.001 * * *$ \\
\hline
\end{tabular}

Df: Degrees of freedom. Signif. codes: 0 ‘***’ 0.001 ‘**’ 0.01 ‘*’ 0.05 ‘’ 0.1 ‘ ‘ 1 
Table 8. The results of the post hoc test (Duncan test) of the seasonal variations for the four metallic trace elements ( $\mathrm{Zn}, \mathrm{Cu}, \mathrm{Pb}$ and $\mathrm{Cd})$ in the liver of common sole fished in the bay of Ghazaouet

\begin{tabular}{|c|c|c|c|}
\hline Organ & Metal & Comparison & $Z$ value \\
\hline \multirow{4}{*}{ Liver } & $\mathrm{Zn}$ & $\begin{array}{c}\text { Autumn - Spring } \\
\text { Autumn - Summer } \\
\text { Spring - Summer } \\
\text { Autumn - Winter } \\
\text { Spring - Winter } \\
\text { Summer - Winter }\end{array}$ & $\begin{array}{c}3.98 \\
-0.49 \\
-4.47 \\
4.77 \\
0.86 \\
5.26 \\
\end{array}$ \\
\hline & $\mathrm{Cu}$ & $\begin{array}{c}\text { Autumn - Spring } \\
\text { Autumn - Summer } \\
\text { Spring - Summer } \\
\text { Autumn - Winter } \\
\text { Spring - Winter } \\
\text { Summer - Winter }\end{array}$ & $\begin{array}{c}1.73 \\
-0.52 \\
-2.25 \\
5.11 \\
3.38 \\
5.63\end{array}$ \\
\hline & $\mathrm{Pb}$ & $\begin{array}{c}\text { Autumn - Spring } \\
\text { Autumn - Summer } \\
\text { Spring - Summer } \\
\text { Autumn - Winter } \\
\text { Spring - Winter } \\
\text { Summer - Winter }\end{array}$ & $\begin{array}{c}-0.62 \\
-4.90 \\
-4.28 \\
0.04 \\
0.66 \\
4.94\end{array}$ \\
\hline & $\mathrm{Cd}$ & $\begin{array}{c}\text { Autumn - Spring } \\
\text { Autumn - Summer } \\
\text { Spring - Summer } \\
\text { Autumn - Winter } \\
\text { Spring - Winter } \\
\text { Summer - Winter }\end{array}$ & $\begin{array}{c}-0.23 \\
-0.92 \\
-0.68 \\
2.47 \\
2.71 \\
3.39\end{array}$ \\
\hline
\end{tabular}

In Ghazaouet bay, seasonal variations of metallic trace elements showed the highest average concentrations were also noted in this region in summer, fall and spring. The lowest concentrations were noted in winter (Fig. 5).

In the liver of these fish, the mean concentrations of $\mathrm{Cd}, \mathrm{Cu}, \mathrm{Pb}$ and $\mathrm{Zn}$ were respectively equal to $0.33 \pm 0.05 \mu \mathrm{g} . \mathrm{g}^{-1} \mathrm{dw}, 6.91 \pm 0.50 \mu \mathrm{g} \cdot \mathrm{g}^{-1} \mathrm{dw}, 1.95 \pm 0.16 \mu \mathrm{g}_{\mathrm{g}} \mathrm{g}^{-1} \mathrm{dw}$, $10.21 \pm 0.80 \mu \mathrm{g} \cdot \mathrm{g}^{-1} \mathrm{dw}$. In winter, they were $0.21 \pm 0.09 \mu \mathrm{g} \cdot \mathrm{g}^{-1} \mathrm{dw}, 4.24 \pm 0.96 \mu \mathrm{g} \cdot \mathrm{g}_{\mathrm{dw}}$, $1.06 \pm 0.29 \mu \mathrm{g} . \mathrm{g}^{-1} \mathrm{dw}, 7.61 \pm 0.77 \mu \mathrm{g} . \mathrm{g}_{\mathrm{dw}}^{-1}$ respectively. In the gills, their highest mean concentrations were reached in summer $0.38 \pm 0.03 \mu \mathrm{g} . \mathrm{g}^{-1} \mathrm{dw}, 7.12 \pm 0.32 \mu \mathrm{g} . \mathrm{g}^{-1} \mathrm{dw}$, $1.92 \pm 0.28 \mu \mathrm{g} . \mathrm{g}^{-1} \mathrm{dw}, \quad 10.86 \pm 0.91 \mu \mathrm{g} . \mathrm{g}^{-1} \mathrm{dw}$ respectively. In winter, they were respectively equal to $0.17 \pm 0.03 \mu \mathrm{g} . \mathrm{g}^{-1} \mathrm{dw}, 4.28 \pm 1.11 \mu \mathrm{g} \cdot \mathrm{g}_{\mathrm{dw}}^{-1}, 1.25 \pm 0.16 \mu \mathrm{g}_{\mathrm{g}} \mathrm{g}_{\mathrm{dw}}$, $7.81 \pm 0.84 \mu \mathrm{g} \mathrm{g}^{-1} \mathrm{dw}$. In the gonads, the maximum concentrations reached in summer were equal to $0.38 \pm 0.04 \mu \mathrm{g} . \mathrm{g}_{\mathrm{dw}}^{-1}, \quad 7.52 \pm 0.62 \mu \mathrm{g} . \mathrm{g}^{-1} \mathrm{dw}, \quad 2.06 \pm 0.19 \mu \mathrm{g} . \mathrm{g}^{-1} \mathrm{dw}$, $11.30 \pm 0.40 \mu \mathrm{g} \cdot \mathrm{g}^{-1} \mathrm{dw}$ and the minima reached in winter, were equal to $0.23 \pm 0.05 \mu \mathrm{g} \cdot \mathrm{g}^{-}$ $1_{\mathrm{dw}}, 4.71 \pm 0.98 \mu \mathrm{g} . \mathrm{g}^{-1}{ }_{\mathrm{dw}}, 1.12 \pm 0.16 \mu \mathrm{g} . \mathrm{g}_{\mathrm{dw}}^{-1}, 7.96 \pm 0.01 \mu \mathrm{g} \cdot \mathrm{g}_{\mathrm{dw}}^{-1}$ respectively. 
Table 9. The results of the post hoc test (Duncan test) of the seasonal variations for the four metallic trace elements ( $\mathrm{Zn}, \mathrm{Cu}, \mathrm{Pb}$ and $\mathrm{Cd}$ ) in the gills of common sole fished in the bay of Ghazaouet

\begin{tabular}{|c|c|c|c|}
\hline Organ & Metal & Comparison & $Z$ value \\
\hline \multirow{4}{*}{ Gills } & $\mathrm{Zn}$ & $\begin{array}{c}\text { Autumn - Spring } \\
\text { Autumn - Summer } \\
\text { Spring - Summer } \\
\text { Autumn - Winter } \\
\text { Spring - Winter } \\
\text { Summer - Winter }\end{array}$ & $\begin{array}{c}3.22 \\
-0.51 \\
-3.73 \\
5.52 \\
2.30 \\
6.03\end{array}$ \\
\hline & $\mathrm{Cu}$ & $\begin{array}{c}\text { Autumn - Spring } \\
\text { Autumn - Summer } \\
\text { Spring - Summer } \\
\text { Autumn - Winter } \\
\text { Spring - Winter } \\
\text { Summer - Winter }\end{array}$ & $\begin{array}{c}0.17 \\
-0.86 \\
-1.02 \\
4.47 \\
4.31 \\
5.33\end{array}$ \\
\hline & $\mathrm{Pb}$ & $\begin{array}{c}\text { Autumn - Spring } \\
\text { Autumn - Summer } \\
\text { Spring - Summer } \\
\text { Autumn - Winter } \\
\text { Spring - Winter } \\
\text { Summer - Winter }\end{array}$ & $\begin{array}{c}-0.43 \\
-4.15 \\
-3.72 \\
1.05 \\
1.48 \\
5.20\end{array}$ \\
\hline & $\mathrm{Cd}$ & $\begin{array}{c}\text { Autumn - Spring } \\
\text { Autumn - Summer } \\
\text { Spring - Summer } \\
\text { Autumn - Winter } \\
\text { Spring - Winter } \\
\text { Summer - Winter }\end{array}$ & $\begin{array}{c}-0.81 \\
-1.49 \\
-0.68 \\
3.95 \\
4.75 \\
5.43\end{array}$ \\
\hline
\end{tabular}

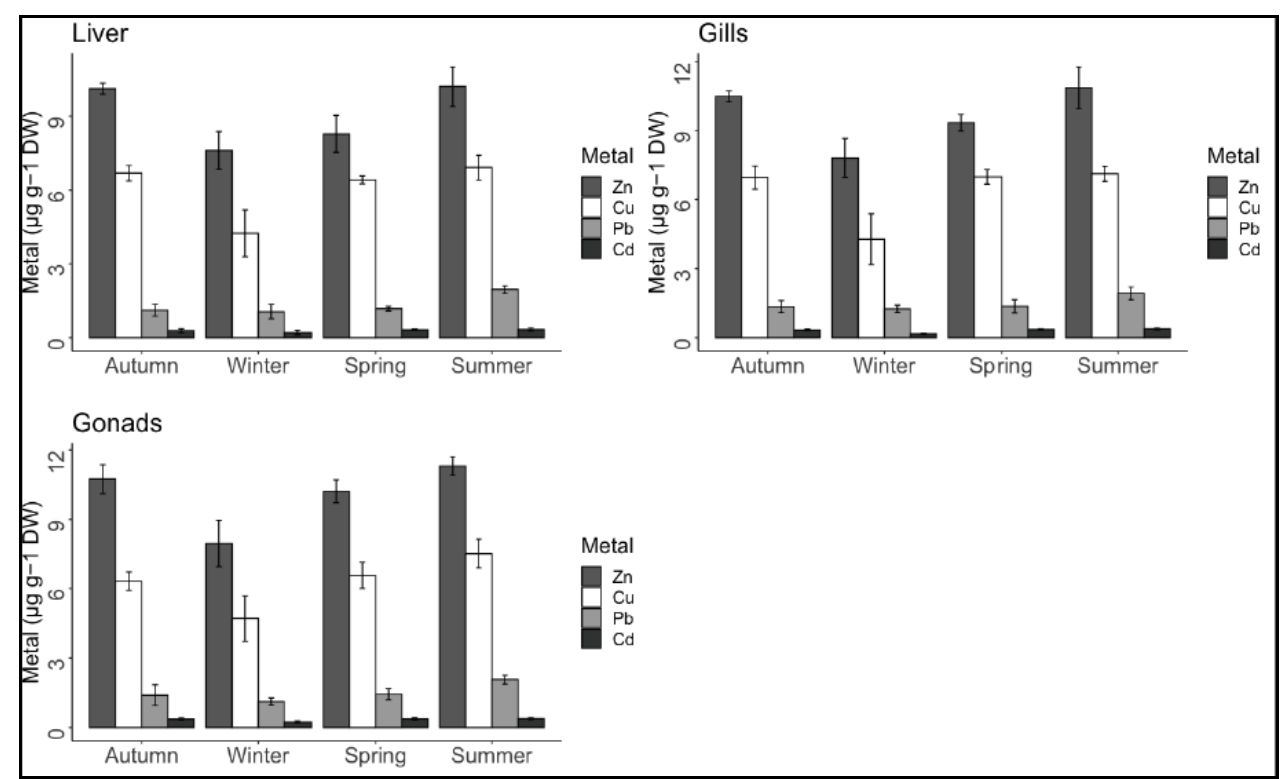

Figure 5. Seasonal variations of metals $(\mathrm{Zn}, \mathrm{Cu}, \mathrm{Pb}$ and $\mathrm{Cd})$ in organs at Ghazaouet bay. 
Table 10. The results of the post hoc test (Duncan test) of the seasonal variations for the four metallic trace elements $(\mathrm{Zn}, \mathrm{Cu}, \mathrm{Pb}$ and $\mathrm{Cd})$ in the gonads of common sole fished in the bay of Ghazaouet.

\begin{tabular}{|c|c|c|c|}
\hline Organ & Metal & Comparison & $Z$ value \\
\hline \multirow{4}{*}{ Gonads } & $\mathrm{Zn}$ & $\begin{array}{c}\text { Autumn - Spring } \\
\text { Autumn - Summer } \\
\text { Spring - Summer } \\
\text { Autumn - Winter } \\
\text { Spring - Winter } \\
\text { Summer - Winter }\end{array}$ & $\begin{array}{c}2.21 \\
-1.37 \\
-3.59 \\
4.95 \\
2.74 \\
6.33\end{array}$ \\
\hline & $\mathrm{Cu}$ & $\begin{array}{c}\text { Autumn - Spring } \\
\text { Autumn - Summer } \\
\text { Spring - Summer } \\
\text { Autumn - Winter } \\
\text { Spring - Winter } \\
\text { Summer - Winter }\end{array}$ & $\begin{array}{c}-0.88 \\
-3.09 \\
-2.21 \\
3.16 \\
4.05 \\
6.26\end{array}$ \\
\hline & $\mathrm{Pb}$ & $\begin{array}{c}\text { Autumn - Spring } \\
\text { Autumn - Summer } \\
\text { Spring - Summer } \\
\text { Autumn - Winter } \\
\text { Spring - Winter } \\
\text { Summer - Winter }\end{array}$ & $\begin{array}{c}-0.27 \\
-4.03 \\
-3.76 \\
1.60 \\
1.87 \\
5.63\end{array}$ \\
\hline & $\mathrm{Cd}$ & $\begin{array}{c}\text { Autumn - Spring } \\
\text { Autumn - Summer } \\
\text { Spring - Summer } \\
\text { Autumn - Winter } \\
\text { Spring - Winter } \\
\text { Summer - Winter }\end{array}$ & $\begin{array}{c}0.62 \\
-0.55 \\
-1.17 \\
4.49 \\
3.87 \\
5.04\end{array}$ \\
\hline
\end{tabular}

The results of base Anova for metallic element variations $(\mathrm{Zn}, \mathrm{Cu}, \mathrm{Pb}$ and $\mathrm{Cd}$ ) between the two sexes of common sole fished in the two bays: bay of Oran and bay of Ghazaouet, are regrouped in Table 11.

Table 11. Anova base of metallic element variations $(\mathrm{Zn}, \mathrm{Cu}, \mathrm{Pb}$ and $\mathrm{Cd}$ ) between the two sexes of common sole fished in the two bays: bay of Oran and bay of Ghazaouet.

\begin{tabular}{c|c|c|c|c|c|c}
\hline Bay & Metal & Df & Sum of squares & Mean of squares & F value & p value \\
\hline \multirow{5}{*}{ Oran bay } & $\mathrm{Zn}$ & 1 & 3.836000 & 3.836000 & 13.3596 & $<0.001 * * *$ \\
& $\mathrm{Cu}$ & 1 & 11.856000 & 11.856000 & 13.8375 & $<0.001^{* * *}$ \\
& $\mathrm{~Pb}$ & 1 & 0.176400 & 0.176400 & 0.6375 & 0.4276 \\
& $\mathrm{Cd}$ & 1 & 0.030013 & 0.030013 & 10.1797 & $<0.05 *$ \\
\hline \multirow{5}{*}{ Ghazaouet bay } & $\mathrm{Zn}$ & 1 & 5.202000 & 5.202000 & 8.7551 & $<0.05 *$ \\
& $\mathrm{Cu}$ & 1 & 0.933000 & 0.932800 & 2.1914 & 0.1437 \\
& $\mathrm{~Pb}$ & 1 & 0.063500 & 0.063490 & 0.9444 & 0.3342 \\
& $\mathrm{Cd}$ & 1 & 0.018689 & 0.018689 & 6.4739 & $<0.05 *$ \\
\hline
\end{tabular}

Df: Degrees of freedom. Signif. codes: 0 ‘***’ 0.001 '**’ 0.01 ‘*’ 0.05 '? 0.1 ‘ ‘ 1 
In terms of the inertias of the factorial axes of the PCA (Fig. 6), the Dim1 axis would explain $68 \%$ of the variance of the concentrations of metallic trace elements between the organs and the Dim2 axis would explain $14.5 \%$.
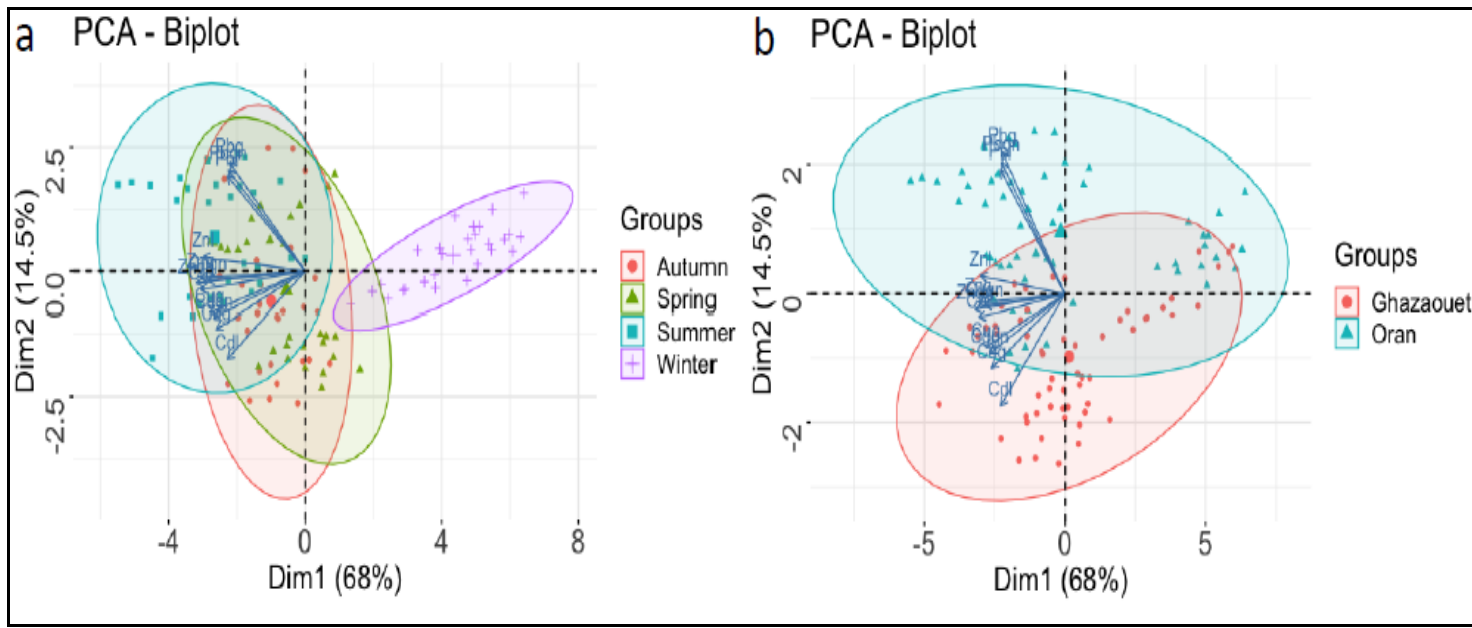

Figure 6. Projection of heavy metals according to the seasons at the two bays: Oran Bay and Ghazaouet Bay. (a) Projection of heavy metals according to the seasons at the two sites studied. (b) Projection of heavy metals according to the sites studied.

\section{Discussion}

The physicochemical results in Table 1 of the water obtained generally comply with Algerian and European standards (JORA, 2006) whether for $\mathrm{T}^{\circ}, \mathrm{pH}$, salinity or even the $\mathrm{O}_{2}$ dissolved.

All of our results concerning temperature are comparable to those obtained by (Rouane-Hacene et al., 2018) $\left(21.40 \pm 1.41{ }^{\circ} \mathrm{C}\right)$ in the same region as well as those of (Dahel, 2009) $\left(20.25{ }^{\circ} \mathrm{C}\right)$ and (Boucetta, 2017) $\left(20.52 \pm 5.37{ }^{\circ} \mathrm{C}\right)$ in the waters of the Algerian coast. According to Imasheva et al. (1997), temperature is considered to be an essential ecological factor in the control of various biological and physiological processes such as metabolism, reproduction, growth and biogeographic distribution of marine species, either directly or in correlation with other ecological factors.

The $\mathrm{pH}$ values in Table 1 taken during the study period did not show significant spatio-temporal fluctuations. In general, for both berries the $\mathrm{pH}$ is slightly alkaline. Our results agree with other values found in previous studies carried out on the Algerian east coast (Boudelaa and Medjram, 2011; Hamdani, 2012; Rouidi et al., 2013) and on the Algerian west coast (Remili and Kerfouf, 2013; Rouane-Hacene et al., 2018; Rouabhi et al., 2019).

According to Boucetta (2017), $\mathrm{pH}$ is a fundamental ecological factor that plays an important role in the marine environment, as it can affect many physiological and biochemical processes. According to Blakeslee et al. (2013), $\mathrm{pH}$ also acts on certain chemical components which can become toxic.

The measured mean salinity value in Table 1 is $(36.57 \pm 0.67)$ psu in the bay of Oran and (36.84) psu in the bay of Ghazaouet, these results agree with those obtained on the Algerian east coast, where the salinity varies between 35 and 38 psu (Sifi, 2009; Hamdani, 2012). 
Numerous studies had shown that species exposed to low levels of salinity increase their oxygen uptake and weaken energy metabolism. Low salinity results in high food consumption (Widmeyer and Bendell-Young, 2007; Mattozo et al., 2012; Rashida et al., 2015). Salinity largely controls biological processes, but also chemical processes in water, it also has an impact on the bioavailability of metals (Mouneyrac et al., 2009).

The dissolved oxygen level reaches its maximum in winter with $\left(8.31 \pm 0.24 \mathrm{mg} \mathrm{L}^{-1}\right)$ in the bay of Oran and $7.89 \pm 0.10 \mathrm{mg} \mathrm{L}^{-1}$ in the bay of Ghazaouet. A gradual drop in its concentrations was observed in summer in both bays. This may be due to the increase in temperature and the impact of hydrodynamics (Florian, 2011). The same observations were made in the gulfs of Annaba and Skikda in the bay of Collo (Guemouda, 2015), in the bay of Algiers (Bachari et al., 2011), and in the bay of Oran (Rouane-Hacene, 2013). It is also noted that a low dissolved oxygen content may be associated with industrial releases and organic pollutants (Boucetta, 2017).

According to Belghiti et al. (2013), dissolved oxygen is one of the parameters most sensitive to pollution, and its concentration tells us about the level of pollution and therefore the degree of self-purification. Indeed, the alteration of the polluting material causes a drop in the dissolved oxygen content in the environment, causing a disturbance in the preservation and development of aquatic flora and fauna (Afri-Mehennaoui, 1998).

According to Karayücel and Karayücel (2000), the physicochemical factors (temperatures, salinity, dissolved oxygen, $\mathrm{pH}$, etc.) of the medium play an important role since they act both on the physicochemical form of metals (adsorption-desorption on suspended metals) therefore on their bioavailability, but also on the metabolism of the species (respiration, reproduction, trophic activities, etc.), which partly influences the kinetics of accumulation and excretion of metals.

Statistical processing of variations in average trace metal contents evaluated in the common sole fished in the two sites (Fig. 2) indicate the presence of very heterogeneous values. $\mathrm{Zn}$ concentrations were highest with $9.77 \pm 1.61 \mu \mathrm{g} \cdot \mathrm{g}_{\mathrm{dw}}^{-1}$ in Oran and $9.58 \pm 1.42 \mu \mathrm{g} . \mathrm{g}^{-1} \mathrm{dw}$ in Ghazaouet, followed by that of $\mathrm{Cu}$ with $6.33 \pm 1.84 \mu \mathrm{g} \mathrm{g}^{-1} \mathrm{dw}$ in Oran and $6.21 \pm 1.25 \mu \mathrm{g} . \mathrm{g}^{-1} \mathrm{dw}$ in Ghazaouet, $\mathrm{Pb}$ with $2.02 \pm 0.75 \mu \mathrm{g} \cdot \mathrm{g}^{-1} \mathrm{dw}$ in Oran and $1.44 \pm 0.41 \mu \mathrm{g} . \mathrm{g}^{-1} \mathrm{dw}$ in Ghazaouet, and finally Cd with $0.25 \pm 0.07 \mu \mathrm{g} . \mathrm{g}^{-1} \mathrm{dw}$ in Oran and $0.31 \pm 0.08 \mu \mathrm{g} \cdot \mathrm{g}^{-1} \mathrm{dw}$ in Ghazaouet. The same classification of the ETM accumulation gradient has often been observed in this region for different marine species (Borsali et al., 2014; Guendouzi et al., 2017; Rouabhi et al., 2019). It is clear that the process of bioaccumulation depends on the extent of the contamination of the medium. The accumulation of metallic trace elements in aquatic organisms results from the net balance of capture and excretion processes. According to Casas (2005), three mechanisms must be taken into account: metal capture, excretion and storage by the organism. According to Di Bella et al. (2006), Bodin et al. (2007) and Belhoucine et al. (2014), the bioaccumulation process is indeed influenced by the physicochemical properties of compounds but also by biological, physiological and specific ecological aspects of the exposed species, such as habitat, sex, age, reproduction, diet or the state of health of the animals. According to other authors, the level of heavy metals in different species depends mainly on eating habits (Mormede and Davies, 2001; Watanabe et al., 2003; Bouhadiba et al., 2017).

Amara et al. (2001) indicates that the common sole S. solea (L. 1758) is a benthic fish which with a diet, consisting of benthic and epi-benthic invertebrates (polychaetes, molluscs and crustaceans), shows variations qualitative and quantitative depending on 
the season, the area and the size of the individuals. Benthic fish generally accumulate higher concentrations of heavy metals than pelagic fish (Bustamante et al., 2003; Belhoucine et al., 2015; Bouhadiba et al., 2017).

The data recorded by (Kerfouf et al., 2010; Remili and Kerfouf, 2013) are practically similar to our results. The latter stressed that the bay of Oran is threatened by various forms of nuisance, industrial activities, intensive tourism and massive urbanization, which generates increasing pollution.

The results of this work also tend to support the observations of Benguedda et al. (2011) who point out the importance of the industrial unit ALZINC (Algerian Zinc Company) in the pollution of the Ghazaouet region. The purpose of this unit is the production and marketing of zinc and its alloys, sulfuric acid, cathodic copper (Benguedda et al., 2011). This plant uses seawater for cooling the sulfuric acid manufacturing facilities and some of the plant's thermal power plant (Bakalem, 1980). According to Belhoucine et al. (2014) anthropogenic inputs of zinc into the environment result mainly from mining activities, agricultural spraying and urban activities. They also assume that domestic wastewater inputs contain $\mathrm{Zn}$. According to the work of (Casas, 2005), in port areas, zinc is introduced from the dissolution of anodes intended to protect boat hulls against corrosion, and is contained in certain anti-fouling paints. For copper, most of it comes from soil erosion by watercourses (68\%) (Casas, 2005), contamination of copper sulphate $(13 \%)$ and discharges of wastewater that still contains copper, even after treatment (Casas, 2005). According to Rouabhi (2020), the high lead concentrations in Oran Bay could be due to the proximity to the Arzew industrial zone responsible for processing and exporting hydrocarbons mainly to Europe. According to Belhoucine et al. (2014) its high concentrations could also be due to the combustion of automotive fuels. Regarding cadmium, according to Miramand et al. (2000) and Bosch et al. (2016), its presence in aquatic environments is mainly of atmospheric origin and also due to leaching of soils (phosphate fertilizers).

The results obtained from the average concentrations of the four metallic trace elements analyzed at the organ level showed no significant variation between the sampling sites and between the two sexes (Anova, $F$ value $=0.01, \mathrm{p}$ value $=0.99$ ) (Table 2). However, the results recorded have made it possible to reveal that the three tissues chosen bioaccumulate all the micropollutants $(\mathrm{Zn}, \mathrm{Cu}, \mathrm{Pb}$ and $\mathrm{Cd}$ ) and appear to have similar concentrations. No significant difference was noted between the three organs studied (Anova, $\mathrm{F}$ value $=0.47, \mathrm{p}$ value $=0.62)($ Table 2$)$ regardless of the site of harvest. Ennouri et al. (2008), El Morhit et al. (2009) and Belhoucine et al. (2014) observed a different accumulation between organs which followed a decreasing scale: Gonads $>$ gills $>$ liver, in different species of fish.

The distribution, location and bioaccumulation of metallic elements in tissues do not depend on a single mechanism (Belhoucine et al., 2014). In fact, the quantity of metals transferred is influenced both by the irrigation of the organ considered and by the intracellular binding capacities (Boudou, 1982). According to this author, the relative importance of these two parameters determines the target organs of metallic bioaccumulation. Therefore, tolerance to such a form of pollution by marine organisms has been attributed to the presence of metallothionein, proteins involved in the processes of storage, bioaccumulation, transport and detoxification (immobilization of heavy metals in non-toxic form inside the cell) (Linde et al., 1999; Evoglu et al., 2005; Atli and Canli, 2008). 
The increase in the levels of metals, which for the most part are not lipophilic contaminants, is due to slower elimination; This may be explained by the role of the liver in detoxifying contaminants and the importance of the gonads in reproductive physiology (Zhang and Wang, 2007).

Numerous studies had shown a preferential organotropism of trace metals such as $\mathrm{Cd}, \mathrm{Cu}$ and $\mathrm{Zn}$ for the liver in fish (De Boeck et al., 2004; Usero et al., 2004; Ribeiro et al., 2005). According to Rouabhi (2020), the gills reflect the bioavailability of contaminants in the medium and according to Capene and Vasak (1989), the liver is more efficient in biomonitoring studies using fish.

Bioaccumulation of toxic metals can affect the liver, gonads, gills and other tissues of fish, resulting in metabolic disruption and obstruction of fish growth and development (Junejo et al., 2019).

The same seasonal variations had been observed in the work of Miramand et al. (2000) for Mullus barbatus from French marine waters. The highest concentrations of metallic trace elements were also reached in the summer season.

Barhoumi et al. (2009) had underlined in their study that the gills are the main targets of direct contamination, because they play an important role in the absorption of metals, in the storage and possibly in the transfer to the internal compartments by the blood. Similar seasonal variations on the Algerian west coast were also observed in the sardine Sardinella aurita (Benamar et al., 2010), in the hake Merluccius merluccius (Belhoucine et al., 2014) and in the Mullets Mugil cephalus (Bouhadiba et al., 2017). According to Belhoucine et al. (2014), the Algerian coastal population increases considerably during the summer, which can increase direct discharges into water.

According to Bennett (1978), the increase in water temperature causes an increase in ventilation of the gills in response to the decrease in the concentration of oxygen in the water. Thus, increased metabolic rate during the summer could lead to increased absorption of bioavailable contaminants in water. In addition, temperature also has a strong influence on the properties of the metal by changing the effect of equilibrium between molecular and ionized forms (El Morhit et al., 2009). Storelli and Marcotrigiano, (2001) conclude in their work that the concentration of metals in fish tissue generally reflects the pollution profile.

On the other hand, it is possible that this difference in bioaccumulation is conditioned by the fluctuation of certain biological factors such as growth and reproduction. These factors contribute greatly to the variability of heavy metal bioaccumulation (Langston and Spence, 1995). Especially since this species spawns mainly in winter (Morat, 2011), which can induce an excretion of contaminants from the organism (Casas, 2005).

No significant difference was observed between the two sexes regardless of the organ studied (Anova, $\mathrm{F}$ value $=0.16, \mathrm{p}$ value $>0.05$ ) or the site of harvest (Anova, $\mathrm{F}$ value $=0.04, p$ value $>0.05)($ Table 2$)$. In Oran, there is a significant variation between the two sexes for $\mathrm{Zn}$ (Anova 3, F value $=13.36$, $\mathrm{p}$ value $<0.001$ ), $\mathrm{Cu}$ (Anova 3, F value $=13.84, \mathrm{p}$ value $<0.001$ ) and $\mathrm{Cd}$ (Anova $3, \mathrm{~F}$ value $=10.18, \mathrm{p}$ value $<0.05$ ) (Table 11). Concerning Ghazaouet bay, there is a significant variation between the two sexes for $\mathrm{Zn}$ (Anova 3, $\mathrm{F}$ value $=8.75, \mathrm{p}$ value $<0.05$ ), and $\mathrm{Cd}$ (Anova 3, F value $=6.47, \mathrm{p}$ value $<0.05)($ Table 11$)$.

Different variations between the two sexes were noted by Belhoucine et al. (2014) in M. merluccius fished at the level of the Oran coastline and Bodiguel et al. (2008) in $M$. merluccius fished in the French Mediterranean (Golf du Lyon). Which can mean that 
gender can influence the accumulation of contaminants under certain conditions due to the difference in growth between males and females.

However, several studies had also shown that there was no difference between the accumulation of contaminants in organs between the two sexes (Lombardi, et al., 2010; Hosseini Alhashemi et al., 2012). This can be explained by the sedentary nature of the common sole (Solea solea, L. 1758) (De Serres, 1845; Wessel, 2010). In fact, males and females in this species have the same ecology and the same behavior, and are constantly in contact with sediments, a compartment that allows the capture of many contaminants such as, for example, metallic trace elements (Wessel, 2010).

The projection of the observations on the Dim1 axis (Fig. 6), shows that the seasonal aspect has a great influence on the distribution of the data. The winter season is the one that shows the most difference compared to the other seasons. Seasonality is one of the most influential factors in the build-up of contaminants. Numerous studies have shown its importance in the accumulation of metallic trace elements by marine species (Kaimoussi et al., 2000; Orban et al., 2002; Belhoucine et al., 2014).

The projection of the observations in relation to the sampling sites (Fig. 6) shows higher $\mathrm{Pb}$ concentrations in the organs of sole sampled in the bay of Oran $\left(2.02 \pm 0.75 \mu \mathrm{g} \mathrm{g}^{-1}{ }_{\mathrm{wd}}\right)$ than those of Ghazaouet bay $\left(1.44 \pm 0.41 \mu \mathrm{g} \mathrm{g}^{-1}{ }_{\mathrm{wd}}\right)$. These high $\mathrm{Pb}$ concentrations may be due to the presence of several important industrial zones in this region (Sonatrach, ammoniac industries and water treatment plants) (Grimes, 2010; Rouabhi, 2020). The concentrations of other metallic trace elements in the region of Ghazaouet mainly those of $\mathrm{Zn}$ may be due to the proximity of the company Alzinc (production and processing of $\mathrm{Zn}$ ) in this region (Benguedda et al., 2011).

These concentrations of trace metal elements can also return to wastewater discharges without prior treatment (Taleb et al., 2007). In addition, this coast is also under the direct influence of maritime traffic which could be the source of trace metals (Belhoucine et al., 2015).

\section{Conclusion}

Marine pollution has been a very worrying universal problem for two decades now. Today, the threat is so great for all seas and oceans, and public concern is so great, that states are individually and collectively seeking the necessary instruments to curb it. Man being the last link in the food chain and the end consumer of marine products can be a victim at any time. The risks of bioavailability and toxicity of these trace metals are to be feared because they constitute permanent dangers for the entire food chain and threaten public health.

This present work, the interest of which we emphasize, allows us to take stock of the current situation of the bay of Oran and the bay of Ghazaouet in terms of coastal and marine environmental pollution.

Regarding the physico-chemical analysis of seawater, parameters: $\mathrm{T}^{\circ}, \mathrm{pH}$, salinity, organic matter or even dissolved $\mathrm{O}_{2}$, our results are in Algerian standards and coincide with previous studies in the same region.

Organs from common sole taken from the two contrasting sites showed the same process of bioaccumulation of metallic trace elements with the same proportions, implying the importance of the physiological role of each organ in the process of bioaccumulation. The average concentrations of metals measured in the tissues of the common sole collected in the two sampling sites, varied according to the seasons, in 
relation to the biology of the animals (growth, reproduction, etc.) and under the influence of certain parameters. environment, mainly temperature. This marked a seasonal variability mainly between the winter period and the summer period.

The results obtained show that the common sole of the Algerian west coast has great potential as a tool for evaluating metal pollution in the marine environment. This work allowed us to highlight the omnipresence of the four metallic trace elements in each target organ of this species. This contamination of fish is a risk factor not only for the life of these aquatic species, but also for humans. To further this study, it is important to carry out toxicological analyzes on the flesh of this fish in order to better assess the potential risks to human health linked to their consumption.

This study would also deserve in the future to extend well and be enriched by expanding the sampling network to the entire Algerian coastline and integrating other trace metals in particular mercury and evaluating organic pollutants such as hydrocarbons, pesticides. On the biological level, we must take into account the biological cycle and the behavior of the bioindicator with respect to contaminants. In addition, it would be very interesting to assess the contamination, distribution and speciation of these xenobiotics in the water column of the Algerian coast and to perform sequential extractions to better identify their mobility within a sediment in order to better correlate the potential toxicity of metallic trace elements in a sediment to the surrounding biological activity.

\section{REFERENCES}

[1] Afri-Mehennaoui, F. Z. (1998): Contribution à l'étude physico-chimique et biologique de l'oued Kebir Rhumel et de ses principaux affluents. - Mémoire de Magistère en écologie. Département de Biologie et Ecologie Végétale, Université de Constantine.

[2] Amara, R., Laffargue, P., Maryniak, C., Lagardere, F., Luzac, C. (2001): Feeding ecology and growth of O-group flatfish (sole, dab and plaice) on a nursery ground (Southern Bight of the North Sea). - Journal of Fish Biology 58(3): 788-803. DOI: 10.1111/j.10958649.2001.tb00531.x.

[3] Amiard-Triquet, C., Amiard, J. C. (2008): Les biomarqueurs dans l'évaluation de l'étatécologique des milieux aquatiques. - Tec \& Doc, Paris.

[4] Atli, G., Canli, M. (2008): Reponses of metallothionein and reduced glutathione in a freshwater fish Oreochromis niloticus following metal exposures. - Environmental Toxicology and Pharmacologie 25: 33-38.

[5] Aydoğan, Z., İncekara, Ü. (2017): Heavy element pollution their meaning in literature and using organisms to monitor this pollution. - https://nbnresolving.org/urn:nbn:de:101:1-201712292883 (accessed: 7 September 2020).

[6] Bachari, S., Houma, F., Bachouche, N., Kessar, A., Belkessa, R. (2011): Contribution to the assessment of pollution of marine water on the west coast of Algeria using satellite imagery. - Con Méd Côt \& Mar. 2nde edition, pp. 339-344.

[7] Bakalem, A. (1980): Aménagement du littoral ouest: problème de pollution marine étude préliminaire de la zone Arzew-mers el Hadjadj. - Cahiers géographiques de l'Ouest 5-6: 115-49

[8] Barhoumi, S., Messaoudi, I., Deli, T., Saïd, K., Kerkeni, A. (2009): Cadmium bioaccumulation in three benthic fish species, Salaria basilisca, Zosterisessor ophiocephalus and Solea vulgaris collected from the Gulf of Gabes in Tunisia. - Journal of Environmental Sciences 21(7): 980-984. DOI: 10.1016/S1001-0742(08)62371-2. 
[9] Belghiti, M. L., Chahlaoui, A., Bengoumi, A. (2013): Caractéristiques physico-chimique des eaux de certains puits utilisés comme source d'eau portable en milieu rural dans la région de Meknès (Maroc). - Larhyss Journal 46: 21-36.

[10] Belhoucine, F., Alioua, A., Bouhadiba, S., Boutiba, Z. (2014): Impact of some biotics and abiotics factors on the accumulation of heavy metals by a biological model Merluccius merluccius in the bay of Oran in Algeria. - Journal of Biodiversity and Environmental Sciences (JBES) 5(6): 33-44.

[11] Belhoucine, F., Habbar, C., Alioua, A., Bouahdiba, S., Mohamed Benkada, M., Benhabara, R., Boutiba, Z. (2015): Assessment of contamination by xenobiotics (lead and cadmium) in the muscle tissue of two teleost spotted weever (Trachinus Araneus, Cuvier, 1829) and the axillary seabream, (Pagellus Acarne, Risso, 1826) in the Algerian West coast. - International Journal of Scientific Research in Science and Technology. DOI: 10.32628/CIBA06.

[12] Benamar, N., Bouderbala, M., Boutiba, Z. (2010): Evaluation de la concentration en cadmium d'un poisson pélagique commun, Sardinella aurita, dans la baie d'Oran. Journal des Sciences Halieutique et Aquatique 1: 16-20.

[13] Benguedda, W., Dali, Y. N., Amara, R. (2011): Trace metals in sediments, macroalgae and benthic species from the western part of Algerian coast. - Journal of Environmental Science and Engineering 15(2): 1604-1612.

[14] Bennett, A. F. (1978): Activity metabolism of the lower vertebrates. - Annual Review of Physiology 40(1): 447-469. DOI: 10.1146/annurev.ph.40.030178.002311.

[15] Benzohra, M., Millot, C. (1995): Characteristics and circulation of the surface intermediate water masses of Algeria. - Deep Sea Research Part I: Oceanographic Research Papers 10(42): 1803-1830.

[16] Blakeslee, C. J., Galbraith, H. S., Robertson, L. S., St John, W. B. (2013): The effects of salinity exposure on multiple life stages of a common freshwater mussel, Elliptio complanata: effects of salinity on Elliptio complanata. - Environmental Toxicology and Chemistry 32(12): 2849-2854. DOI: 10.1002/etc.2381.

[17] Bodiguel, X., Tronczyński, J., Loizeau, V., Munschy, C., Guiot, N., Le Guellec, A. M., Olivier, N., Roupsard, F., Mellon, C. (2008): Classical and novel organohalogen compounds (PCBs and PBDEs) in hake (M. merluccius, L.) from the Mediterranean and Atlantic coasts (France). - Environmental Toxicology. DOI: 10.2495/ETOX080171.

[18] Bodin, N., Caisey, X., Abarnou, A., Loizeau, V., Latrouite, D., Le Guellec, A., Guillou, M. (2007): Polychlorinated biphenyl contamination of the spider crab (MAJA BRACHYDACTYLA): Influence of physiological and ecological processes. Environmental Toxicology and Chemistry 26(3): 454. DOI: 10.1897/06-076R.1.

[19] Borsali, S. (2015): Evaluation de la contamination métallique dans trois organes (foie, gonades et muscle) du Rouget de roche Mullus surmuletus (L.1758) par quatre métaux lourds $(\mathrm{Zn}, \mathrm{Cu}, \mathrm{Cd}, \mathrm{Pb})$ peché dans la baie d'Oran. - Thése de Doctorat. Université d'Oran, Oran.

[20] Borsali, S., Bouderbala, M., Boutiba, Z. (2014): Evaluation of metal contamination of mullet (Mullus surmuletus L. 1758) in the Bay of Oran. - Journal of Life Sciences 8(4): 344-350.

[21] Bosch, A. C., O’Neill, B., Sigge, G. O., Kerwath, S. E., Kerwath, L. C. (2016): Heavy metals in marine fish meat and consumer health: a review: heavy metals in marine fish meat. - Journal of the Science of Food and Agriculture 96(1): 32-48. DOI: 10.1002/jsfa.7360.

[22] Boucetta, S. (2017): Biosurveillance des eaux du littoral Est algérien à travers un mollusque gastropode: Phorcus (=Osilinus) turbinatus (BORN, 1780). - Thése de Doctorat es sciences. Départements des sciences de la Mer. Université Badji Mokhtar, Annaba. 
[23] Boucheseiche, C., Cremille, E., Pelte, T., Pojer, K. (2002): Bassin Rhône - Méditerranée Corse. - Guide technique $n^{\circ}$, Pollution toxique et écotoxicologie: notion de base. Lyon, Agence de l'Eau Rhône - Méditerranée - Corse.

[24] Boudelaa, S., Medjram, M. S. (2011): Assessment of chemical and petrochemical effluent: case of hydrocarbon pole of skikda, Algeria. - European Journal of Scientific Research 4(63): 563-584.

[25] Boudou, A. (1982): Recherches en éco toxicologie expérimentale sur les processus de bioaccumulation et de transfert des dérivés du mercure. - Thèse de doctorat d'Etat. Université de Bordeaux 1, Bordeaux.

[26] Bouhadiba, S., Belhoucine, F., Belhadj, H., Alioua, A., Boutiba, Z. (2017): Quantification of two metallic elements in the Mullet, Mugil cephalus Linnaeus, 1758 (Perciformes Mugilidae), fished at the bay of Oran (NW Algeria). - Biodiversity Journal 8(3): 807818.

[27] Bustamante, P., Bocher, P., Chérel, Y., Miramand, P., Caurant, F. (2003): Distribution of trace elements in the tissues of benthic and pelagic fish from the Kerguelen Islands. Science of the Total Environment 313(1-3): 25-39. DOI: 10.1016/S0048-9697(03)002651.

[28] Capene, E., Vasak, M. (1989): Hepatic metallothionein from goldfish (Carassius auratus). - Comparative Biochemistry and Physiology 92(3): 463-468.

[29] Casas, S. (2005): Modélisation de la bioaccumulation des métaux traces ( $\mathrm{Hg}, \mathrm{Cd}, \mathrm{Pb}, \mathrm{Cu}$ et $\mathrm{Zn}$ ) chez la moule, mytulus galloprovincialis, en milieu méditerranéen. - Doctorat de l'université du sud de Toulon Var. l'université du sud de Toulon Var.

[30] Chiffoleau, J. F., Claisse, D., Cossa, D., Ficht, A., Ganzalez, J. L., Guyot, T., Michel, P., Miramand, P., Oger, C., Petit, F. (2001): La contamination métallique. Programme Seine Aval, fascicule $n^{\circ} 8,-$ Editions Ifremer, Plouzané (France).

[31] Dahel Zanat Amina-Tania. (2009): Analyse de la qualité bactériologique des eaux du littoral Nord-Est algérien à travers un bioindicateur la moule Perna perna. - Magister en Sciences de la Mer. Département des Sciences de la Mer. Université Badji-Mokhtar, Annaba.

[32] De Boeck, G., Petit, W., De Coen, W., Blust, R. (2004): Tissue-specific Cu bioaccumulation patterns and differences in sensitivity to waterborne $\mathrm{Cu}$ in three freshwater fish: rainbow trout (Oncorhynchus mykiss), common carp (Cyprinus carpio), and gibel carp (Carassius auratus gibelio). - Aquatic Toxicology (Amsterdam, Netherlands) 70(3): 179-188. DOI: 10.1016/j.aquatox.2004.07.001.

[33] De Serres, M. (1845): Des causes des migrations des animaux, et particulièrement des oiseaux et des poissons. Volume 1. - Lagny frères, Paris.

[34] Di Bella, G., Licata, P., Bruzzese, A., Naccari, C., Trombetta, D., Lo Turco, V., Dugo, G., Richetti, A., Naccari, F. (2006): Levels and congener pattern of polychlorinated biphenyl and organochlorine pesticide residues in bluefin tuna (Thunnus thynnus) from the Straits of Messina (Sicily, Italy). - Environment International 32(6): 705-710. DOI: 10.1016/j.envint.2006.02.001.

[35] DPRHT (2004): Le secteur de la pêche et de l'état environnemental du littoral de la Wilaya de Tlemcen, 41P. Direction de la Pêche et des Ressources Halieutiques de Tlémcen, Algérie.

[36] Dusquene, S. (1992): Bioaccumulation métallique et métallothioneines chez trois espèces de poissons du littoral Nord-Pas De Calais. - Thèse de Doctorat en Biologie et Santé. Université des Sciences et Techniques de Lille.

[37] El Morhit, M., Fekhaoui, M., Elie, P., Girard, P., Yahyaoui, A., El Abidi, A., Jbilou, M. (2009): Heavy metals in sediment, water and the european glass eel, Anguilla anguilla (Osteichthyes: Anguillidae), from Loukkos River estuary (Morocco, eastern Atlantic). Cybium: International Journal of Ichthyology 33(3): 219-228. DOI: https://doi.org/10.26028/cybium/2009-333-005. 
[38] Ennouri, R., Chouba, L., Kraiem, M. M. (2008): Evaluation de la contamination chimique par les metaux traces $(\mathrm{Cd}, \mathrm{Pb}, \mathrm{Hg}$ et $\mathrm{Zn}$ ) du zooplancton et de la sardinelle (Sardinella aurita) dans le golf de Tunis. - Bulletin de l'Institut National des Sciences et Technologies de la Mer,33.

[39] Evoglu, K., Atli, G., Canli, M. (2005): Effects of metal (Cd, Cu, Zn) interactions on the profiles of metallothionein-like proteins in the Nile fish Oreochromis niloticus. - Bulletin of Environmental Contamination and Toxicology 75(2): 309-399.

[40] Florian, G. (2011): Rôle des herbiers de zostères (Zostera noltii) sur la dynamique sédimentaire du Bassin d'Arcachon. Rôle des herbiers de zostères (Zostera noltii) sur la dynamique sédimentaire du Bassin d'Arcachon. - Thèse de Doctorat. Université de Bordeaux 1, Bordeaux.

[41] Förstner, U., Wittmann, G. T. W. (1981): Metal Pollution in the Aquatic Environment. $2^{\text {nd }}$ Ed. - Springer, Berlin.

[42] Goldberg, E. D. (1975): The "Mussel Watch" Mar. - Pollut. Bull. 6: 111-113.

[43] Grimes, S. (2010): Peuplements benthiques des substrats meubles de la côte algérienne: Taxonomie, structure et statut écologique. - Thése de Doctorat es sciences. Université d'Oran, Oran.

[44] Grimes, S., Ruellet, T., Dauvin, J. C., Boutiba, Z. (2010): Ecological quality status of the soft-bottom communities on the algerian coast: general patterns and diagnosis. - Marine Pollution Bulletin 60(11): 1969-1977. DOI: 10.1016/j.marpolbul.2010.07.032.

[45] Guemouda, M. (2015): Impact de la pollution par les hydrocarbures sur Perinereis cultrifera (Annélides, Polychètes) dans le littoral Est-Algérien. - Thèse de doctorat. Département de Biologie. Université Badji Mokhtar. Annaba.

[46] Guendouzi, Y., Soualili, D. L., Boulahdid, M., Boudjellal, B. (2017): Biological indices and monitoring of trace metals in the mussel from the southwestern Mediterranean (Algeria): seasonal and geographical variations. - Thalass An Int J Mar Sci. 1(34): 103112.

[47] Hamdani, A. (2012): La reproduction chez un mollusque bivalve Donax trunculus L. dans le golfe d'Annaba. Rapport entre les aspects cytologique et biochimique et la pollution. - Thèse de doctorat. Département de Biologie. Université Badji Mokhtar, Annaba.

[48] Hosseini Alhashemi, A., Karbassi, A., Hassanzadeh, K. B., Monavari, S. M., Sekhavatjou, M. (2012): Bioaccumulation of trace elements in different tissues of three commonly available fish species regarding their gender, gonadosomatic index, and condition factor in a wetland ecosystem. - Environmental Monitoring and Assessment 184(4): 1865-1878. DOI: 10.1007/s10661-011-2085-8.

[49] IAEA (1995): Echantillons pour comparaisons inter-oratoire, Matière de référence. Doc. Des Services de contrôle de la qualité des Analyses. 40p. International Atomic Energy Agency.

[50] Imasheva, A. G., Loeschcke, V., Zhivotovsky, L. A., Lazebny, O. E. (1997): Effects of extreme temperatures on phenotypic variation and developmental stability in Drosophila melanogaster and Drosophila buzzatii. - Biological Journal of the Linnean Society 61(1): 117-126. DOI: 10.1111/j.1095-8312.1997.tb01780.x.

[51] JORA (2006): Journal Officiel de la République Algérienne Et Populaire. - 46 executive decree $\mathrm{n}^{\circ}$ 93-164, Directive 2006/7 / CE.

[52] Junejo, S. H. Baig, J. A., Kazi, T. J., Afridi, H. I. (2019): Cadmium and lead hazardous impact assessment of pond fish species. - Biological Trace Element Research 191(2): 502-511. DOI: 10.1007/s12011-018-1628-z.

[53] Kaimoussi, A., Chafik, A., Cheggour, M., Mouzdahir, A. F., Bakkas, S. (2000): Variations saisonnières des concentrations en métaux ( $\mathrm{Cd}, \mathrm{Cu}, \mathrm{Zn}, \mathrm{Fe}$ et $\mathrm{Mn})$ chez la moule Mytilus galloprovincialis du littoral de la région d'El Jadida (Maroc). - Marine Life 10(1-2): 77-85. 
[54] Karayücel, S., Karayücel, I. (2000): The effect of environmental factors, depth and position on the growth and mortality of raft-cultured blue mussels (Mytilus edulis L.). Aquaculture Research 31: 893-899.

[55] Kerfouf, A., Alaoui, F. Z., Djoudi, O., Mebarki, Z., Benyahia, M. (2010): Le dessalement de l'eau de mer dans la perspective d'une gestion intégrée et d'un développement durable: Cas de la station de dessalement d'Oran: Algérie Nord Occidentale. - European Journal of Scientific Research 96(2): 245-249.

[56] Lafabrie, C. (2007): Utilisation de Posidonia oceanica (L) Delile comme bio-indicateur de la contamination métallique. - Thèse de Doctorat en écologie marine. Univerité De Corse. Corse.

[57] Lagadic, L., Caquet, T., Amirad, J. O., Ramade, F. (1998): Utilisation de biomarqueurs pour la surveillance de la qualité de l'enviroimement. - Lavoisier, Paris.

[58] Langston, W. J., Spence, S. K. (1995): Biological Factors Involved in Metal Concentrations Observed in Aquatic Organisms. - In: Tessier, A., Turner, D. R. (eds.) Metal Speciation and Bioavailability in Aquatic Systems. John Wiley \& Sons, London, pp. 407-478.

[59] Linde, A. R., Sánchez-Galán, S., Klein, D., Garcia-Vázquez, E., Summer, K. H. (1999): Metallothionein and heavy metals in brown trout (Salmo trutta) and European Eel (Anguilla anguilla): a comparative study. - Ecotoxicology and Environmental Safety 44: 168-173.

[60] Lombardi, P. E., Peri, S. I., Verrengia Guerrero, N. R. (2010): Trace metal levels in Prochilodus lineatus collected from the La Plata River, Argentina. - Environmental Monitoring and Assessment 160(1-4): 47-59. DOI: 10.1007/s10661-008-0656-0.

[61] Mattozo, V., Binelli, A., Parolini, M., Previato, M., Masiero, L., Finos, L. (2012): Biomarker responses in the clam Ruditapes philippinarum and contamination levels in sediments from seaward and landward sites in the Lagoon of Venice. - Ecological Indicators, (19): 191-205.

[62] Meyer, O. (2003): Testing and assessment strategies, including alternative and new approaches. - Toxicol. Lett 140-141: 21-30.

[63] Miramand, P., Guyot, T., Pigeot, J., Bustamante, P., Caurant, F., Ferchaud, R. (2000): Le cadmium dans les réseaux trophiques marins: de la source aux consommateurs. - Journal européen d'hydrologie 31(2): 127-143. DOI: 10.1051/water/20003102127.

[64] Morat, F. (2011): Influence des apports rhodaniens sur les traits d'histoire de vie de la sole commune (Solea solea): apports de l'analyse structurale et minéralogique des otolithes. - Thèse de doctorat. Université d'Aix Marseille II, Marseille.

[65] Morillo, J., Usero, J., Gracia, I. (2005): Biomonitoring of trace metals in a mine-polluted estuarine system (Spain). - Chémosphere 58: 1421-1430.

[66] Mormede, S., Davies, I. M. (2001): Heavy metal concentrations in commercial deep-sea fish from the Rockall Trough. - Continental Shelf Research 21(8-10): 899-916. DOI: 10.1016/S0278-4343(00)00118-7.

[67] Mouneyrac, C., Durou, C., Gillet, P., Hummel., H., Amiard, T. C. (2009): Linking Energy Metabolism, Reproduction, Abundance, and Structure of Nereis Diversicolor Populations. - In: Amiard-Triquet, C., Rainbow, P. S. (eds.) Environmental Assessment of Estuarine Ecosystems A Case Study. CRC, Boca Rarton, FL.

[68] Ogle, D., Wheeler, P., Dinno, A. (2020): Package « FSA » Title Simple Fisheries Stock Assessment Methods. - https://cran.r-project.org/.

[69] Orban, E., Di Lena, G., Nevigato, T., Casini, I., Marzetti, A., Caproni, R. (2002): Seasonal changes in meat content, condition index and chemical composition of mussels (Mytilus galloprovincialis) cultured in two different Italian sites. - Food Chemistry 77(1): 57-65. DOI: 10.1016/S0308-8146(01)00322-3.

[70] Pal, R., Dubey, R. K., Dubey, S. K., Singh, A. K., Nitant, A. K. (2018): Assessment of heavy metal and organic pollution in Yamuna river at Etawah district of Uttar Pradesh. International Journal of Chemical Studies 6(1): 399-402. 
[71] R Core Team. (2017): The R Project for Statistical Computing. - https://www.rproject.org/.

[72] Rashida, Q., Olufemi, A., Rana., M., Rahim, A. A. (2015): Seasonal variation in occurrence of heavy metals in Perna Viridis from Manora Channel of Karachi, Arabian Sea. - International Journal of Marine Science 5(45): 1-13.

[73] Remili, S., Kerfouf, A. (2013): Évaluation de la qualité physico-chimique et du niveau de contamination métallique $(\mathrm{Cd}, \mathrm{Pb}, \mathrm{Zn})$ des rejets d'eaux usées d'Oran et de Mostaganem (littoral Ouest algérien). - Physio-Géo 7: 165-182. DOI: 10.4000/physio-geo.3258.

[74] Ribeiro, C. A. O., Vollaire, Y., Sanchez, C. A., Roche, H. (2005): Bioaccumulation and the effects of organochlorine pesticides, PAH and heavy metals in the Eel (Anguilla anguilla) at the Camargue Nature Reserve, France. - Aquatic Toxicology (Amsterdam, Netherlands) 74(1): 53-69. DOI: 10.1016/j.aquatox.2005.04.008.

[75] Rodrigue, K. A., Yao, B., Trokourey, A., Kopoin, A. (2016): Assessment of heavy metals contamination in sediments of the Vridi Canal (Cote d'Ivoire). - Journal of Geoscience and Environment Protection 4(10): 65-73. DOI: 10.4236/gep.2016.410004.

[76] Rouabhi, Y. L. (2020): Étude comparative de la biologie et de la bioaccumulation des métaux traces chez deux Mytilidae: Mytilus galloprovincialis Lamarck, 1819 et Perna perna (Linnaeus, 1758) de la côte ouest algérienne. - Thèse de doctorat. Université de Mons, Belgique.

[77] Rouabhi, Y. L., Grosjean, P., Boutiba, Z., Rouane-Hacene, O., Richir, J. (2019): Reproductive cycle and follicle cleaning process of Mytilus galloprovincialis (Mollusca: Bivalvia) from a polluted coastal site in Algeria. - Invertebrate Reproduction \& Development 63(4): 255-267. DOI: 10.1080/07924259.2019.1631221.

[78] Rouane-Hacene, O. (2013): Biosurveillance de la qualité des eaux côtières du littoral ccidental algérien, par le suivi des indices biologiques, de la biodisponibilité et la bioaccumulation des métaux lourds $(\mathrm{Zn}, \mathrm{Cu}, \mathrm{Pb}$ et $\mathrm{Cd})$ chez la moule Mytilus galloprovincialis et l'oursin Paracentrotus lividu. - Thèse de doctorat. Département de Biologie. Université d'Oran, Oran.

[79] Rouane-Hacene, O., Boutiba, Z., Benaissa, M., Belhouari, B., Francour, P., Guibbolini, S. M., Faverney, C. R. (2018): Seasonal assessment of biological indices, bioaccumulation, and bioavailability of heavy metals in sea urchins Paracentrotus lividus from Algerian west coast, applied to environmental monitoring. - Environmental Science and Pollution Research 25(12): 11238-11251. DOI: 10.1007/s11356-017-8946-0.

[80] Rouidi, S., Hadjem, A., Asia, L., Mille, G., Tahar, A. (2013): Sources and distribution of hydrocarbons in surface sediments of saf-saf oued (Skikda city, northeastern Algeria). Annals of Biological Research 4(4): 61-69.

[81] Sifi, K. (2009): Biosurveillance de la qualité des eaux du golfe d'Annaba: croissance, composition biochimique et dosage de biomarqueurs du stress environnemental chez Donax trunculus (Mollusque, Bivalve). - Thèse de Doctorat en Ecotoxicologie. Université de Badji Mokhtar, Annaba.

[82] Storelli, M. M. and Marcotrigiano, G. O. (2001): Heavy metal monitoring in fish, bivalve molluscs, water, and sediments from Varano Lagoon, Italy. - Bulletin of Environmental Contamination and Toxicology 66(3): 365-370. DOI: 10.1007/s001280014.

[83] Taleb, Z., Benghali, S., Kadour, A. S., Boutiba, Z. (2007): Monitoring the biological effects of pollution on the Algerian west coast using mussels Mytilus galloprovincialis. Oceanologia 4(49).

[84] Usero, J., Izquierdo, C., Morillo, J., Gracia, I. (2004): Heavy metals in fish (Solea vulgaris, Anguilla anguilla and Liza aurata) from salt marshes on the southern Atlantic coast of Spain. - Environment International 29(7): 949-956. DOI: 10.1016/S01604120(03)00061-8.

[85] Watanabe, K., Desimone, F., Thiyagarajah, A., Hartley, W., Hindrichs, A. (2003): Fish tissue quality in the lower Mississippi River and health risks from fish consumption. - 
The Science of the Total Environment 302(1-3): 109-126. DOI: 10.1016/S00489697(02)00396-0.

[86] Wessel, N. (2010): Étude des voies de bioactivation du benzo[a]pyrène et du fluoranthène chez la sole commune (Solea solea): Profil métabolique et génotoxicité. - Université de Nantes, Nante.

[87] Wickham, H. (2016): ggplot2p. Chap. 2: Getting Started with ggplot2. - Springer, New York, pp. 11-31.

[88] Wickham, H., Romain, F., Kirill, M. (2020): CRAN - Package dplyr. - https://cran.rproject.org/web/packages/dplyr/index.html (accessed: 7 Sept 2020).

[89] Widmeyer, J. R., Bendell-Young, L. I. (2007): Influence of food quality and salinity on dietary cadmium availability in Mytilus trossulus. - Aquatic Toxicology 2(81): 144-151.

[90] Wright, K. (2018): Package « corrgram » Plot a Correlogram. - https://cran.r-project.org/.

[91] Zhang, L., Wang, W.-X. (2007): Waterborne cadmium and zinc uptake in a euryhaline teleost Acanthopagrus schlegeli acclimated to different salinities. - Aquatic Toxicology 84(2): 173-181. DOI: 10.1016/j.aquatox.2007.03.027. 